\title{
PLACER PLATINUM-GROUP MINERALS IN THE SHETLAND OPHIOLITE COMPLEX DERIVED FROM ANOMALOUSLY ENRICHED PODIFORM CHROMITITES.
}

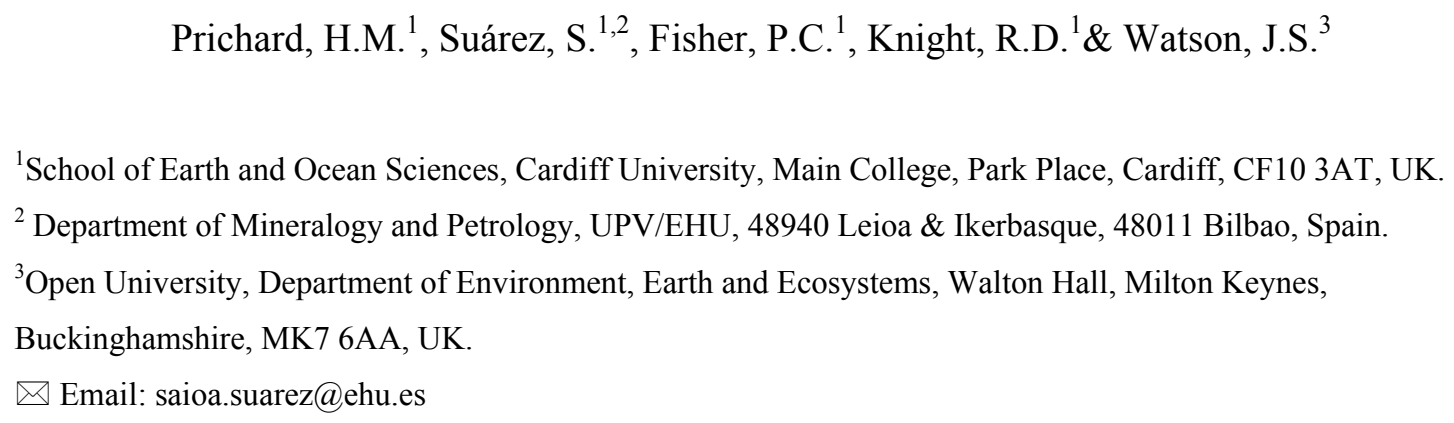

Abstract. Highly anomalous platinum-group element (PGE) concentrations in the podiform chromitites at the Cliff and Harold's Grave localities in the Shetland ophiolite complex have been well documented previously. The focus of this study is alluvial platinum-group minerals (PGM) located in small streams that drain from the PGE-rich chromitites. The placer PGM assemblage at Cliff is dominated by Pt-arsenides (64\%) and Pd-antimonides (17\%), with less irarsite-hollingworthite (11\%) and minor Pd-sulfides, Pt-Pd-Cu and Pt-Fe alloys, and laurite. Gold also occurs with the PGM. Alluvial PGM have average sizes of 20 x $60 \mu \mathrm{m}$, with sperrylite the largest grain identified at $110 \mu \mathrm{m}$ in diameter, matching the range reported for the primary PGM in the source rocks. The placer assemblage contains more Pt-bearing and less Pd-bearing PGM compared with the rocks. The more resistant sperrylite and irarsitehollingworthite grains which are often euhedral become more rounded further downstream whereas the less resistant Pd-antimonides which are commonly subhedral may become striated and etched. Less stable phases such as Pt- and Pd-oxides and other Ni-Cu-bearing phases located in the rocks (i.e. Ru-pentlandite, $\mathrm{PtCu}, \mathrm{Pd}-\mathrm{Cu}$ alloy) are absent in the placer assemblage. Also the scarce PGM (PdHg, Rh- and Ir-Sb) and Os in the rocks are absent. At Harold's Grave only 3 alluvial PGM (laurite, Ir, Os) and Au were recovered reflecting the 
30 limited release of IPGM from chromite grains in the rocks. In this cold climate with high

31 rainfall, where erosion dominates over weathering, the PGM appear to have been derived

32 directly from the erosion of the adjacent PGE-rich source rocks and there is little evidence of

33 in situ growth of any newly formed PGM. Only the presence of dendritic pure Au and Pd-,

$34 \mathrm{Cu}$-bearing Au covers on the surface of primary minerals may indicate some local

35 reprecipitation of these metals in the surficial conditions.

36 Keywords: Shetland ophiolite complex, Cliff, Harold's Grave, alluvial concentrates,

37 platinum-group minerals, platinum-group elements.

\section{Introduction}

40 There are many examples of placer PGM around the world as summarised in Cabri et al.

41 (1996) and Weiser (2002). Placer PGM exhibit variable shapes, commonly form flakes or are 42 rounded or knobbly, and more than $90 \%$ of placer PGM are alloys of Pt-Fe and Os-Ir-Ru-Pt.

43 Ophiolitic placer PGM tend to be dominated by Os-Ir-Ru alloys (Cabri et al., 1996).

45 There is a long standing debate about whether placer PGM erode mechanically from PGE-

46 bearing rocks or whether they grow in situ in stream banks draining from PGE-bearing

47 sources. One of the main lines of evidence for mechanical erosion comes from PGM nuggets

48 that contain inclusions of igneous silicates and exotic PGM that may have been preserved in

49 the matrix of the nuggets. Commonly, placer nuggets are much bigger than the PGM in the

50 source rocks. The argument here is that large PGM in the streams represent the few large

51 PGM concentrated from extensive erosion of the host rocks (Cabri and Harris, 1975) and are

52 overlooked in geochemical and petrological surveys. The alternative view is that placer

53 nuggets may grow in situ in streams. Destruction of PGM by weathering and erosion of the

54 host rocks would liberate the PGE, which may travel downstream in solution and re- 
55 precipitate due to changes in the geochemistry of the PGE-bearing solutions (e.g. Bowles, 56 1986; Bowles et al., 2000). PGM in the host rocks often show evidence of being broken 57 down and oxidised as they weather (Bowles et al., 2017a), thus destroying the PGM for later

58 re-precipitation in the streams. The secondary precipitation of placer PGM has been

59 evidenced by reworking and concentric growths (e.g. Cabral et al., 2009; Zaccarini et al., 60 2013), or by delicate arrangements of PGM (e.g. Bowles et al., 2017b) inconsistent with 61 pervasive mechanical and hydraulic erosion of the grains.

63 Podiform chromitites in ophiolite complexes are typically enriched in IPGE ( $\mathrm{Ir}, \mathrm{Ru}, \mathrm{Os}$ ) over 64 PPGE (Pt, Pd, Rh) and are characterized by Ru-Os-Ir-dominant PGM (IPGM), mainly 65 laurite-erlichmanite $\left(\mathrm{RuS}_{2}-\mathrm{OsS}_{2}\right)$, irarsite (IrAsS), and $\mathrm{Os}-\mathrm{Ir}-\mathrm{Ru}$ alloys. Relevant examples 66 are compiled, for example, in Prichard and Brough (2009) and O'Driscoll and González67 Jiménez (2016). Some other ophiolitic chromitites are however significantly enriched in 68 PPGE and contain Pt-, Pd-, and Rh-bearing minerals (PPGM), e.g. sperrylite (PtAs 2 , 69 stibiopalladinite $\left(\mathrm{Pd}_{5} \mathrm{Sb}_{2}\right)$, isoferroplatinum $\left(\mathrm{Pt}_{3} \mathrm{Fe}\right)$, cooperite--braggite ( $\left.\mathrm{PtS}-\mathrm{PdS}\right)$, and $\mathrm{Pt}-$ $70 \mathrm{Pd}-\mathrm{Rh} \pm$ base-metal alloys (González-Jiménez, 2014). Some well known examples are 71 chromitites from Thetford Mines (Corrivaux and Laflamme, 1990) and Newfoundland (Baie 72 Verte Peninsula; Escayola et al., 2011) in Canada, Leka in Norway (Pedersen et al., 1993), 73 Cabo Ortegal in Spain (Moreno et al., 1999, 2001), Bragança in Portugal (Bridges et al., 74 2013), Albanian ophiolites (Ohnenstetter et al., 1999), Pindos in Greece (Grammatikopoulos 75 et al., 2007; Prichard et al., 2008a), Berit in Turkey (Kozlu et al., 2014), Al'Ays in Saudi 76 Arabia (Prichard et al., 2008b), Acoje in the Philippines (Bacuta et al., 1988; Orberger et al., 77 1988) and Pirogues in New Caledonia (Augé et al., 1998). 
79 The Shetland ophiolite situated on Unst, the most northerly of the Shetland Islands, northeast

80 of Mainland Scotland, was one of the first ophiolite complexes found to contain chromitites

81 enriched in both IPGM and PPGM, with all six PGE being present at ppb or ppm levels

82 (Prichard et al., 1986). The history of their discovery is described in Brough et al. (2015).

83 Prichard et al. (2008b) and Prichard and Brough (2009) concluded that the PPGE-rich

84 chromitites in ophiolites formed from magmas that were close to sulfide liquid saturation,

85 resulting in the local accumulation of traces of strongly PGE-enriched sulfide liquid.

87 The Shetland ophiolite consists of mantle harzburgite overlain by crustal dunite, wehrlite, 88 pyroxenite and gabbro, with a few dykes intruded into the gabbro at the top of the sequence

89 (Fig. 1) (Prichard, 1985; Flinn, 1985). The mantle and crustal ultramafics contain

90 disseminated chromite and there are a number of podiform chromitites in the mantle that are

91 surrounded by an envelope of dunite enclosed in harzburgite. Not all of these pods are

92 enriched in PGE with concentrations of only 10-100 ppb. The exceptions are localities at

93 Cliff and Harold's Grave where enrichment is at ppm levels (up to 58 and 14 ppm total PGE,

94 respectively). The Cliff locality is enriched in all six PGE and is the main focus of this study

95 whereas the Harold's Grave locality is enriched in IPGE (Prichard and Brough, 2009).

97 There have been a number of studies of the PGM in the Shetland ophiolite. Generally the

98 PGM in the chromitites are characterised by euhedral Os-Ir-bearing laurite included within

99 the chromite grains and Os-Ir-barren laurite of irregular shape where the laurite is in contact

100 with the serpentine interstitial to the chromite grains. This interstitial laurite is often

101 accompanied by native Os, irarsite and ruthenian pentlandite (Prichard et al., 1986; Tarkian

102 and Prichard, 1987; Prichard et al., 1994). Occasional composite grains consisting of more

103 varied PGM do, however, occur as for example in the chromitite pod at Nikkavord North, 
104 South Cliff, which consists of laurite, irarsite, hollingworthite (RhAsS), ruthenian

pentlandite, Ni-Rh antimonide and native Os (Prichard et al., 1986). The PGM assemblage in the overlying crustal dunite, wehrlite and pyroxenite sequence contain IPGM in discontinuous chromite layers and PPGM in adjacent sulfide-bearing dunite including Pt-, Pd-rich stibiopalladinite, geversite $\left(\mathrm{PtSb}_{2}\right)$, genkinite $\left((\mathrm{Pt}, \mathrm{Pd})_{4} \mathrm{Sb}_{3}\right), \mathrm{Pt}-\mathrm{Fe}-\mathrm{Cu}$ alloys and $\mathrm{Pt}-$ and Pd-oxides and ochres, which are low-reflectance minerals formed during the alteration of earlier PGM (Prichard et al., 1994). The wehrlite contains a mineral assemblage formed from a more fractionated magma consisting of $\mathrm{Pd}-\mathrm{Cu}$ sulfide and $\mathrm{Pd}-\mathrm{Pb}$ alloys $\pm \mathrm{Pt}$ and $\pm \mathrm{Au}$ in unaltered clinopyroxenite, with Pt and Pd arsenides, antimonides and tellurides in adjacent serpentine (Prichard et al., 1994). The PGM located in different stratigraphic levels and in the different chromitite pods within the mantle have been summarised in Prichard et al. (1994).

The present study focuses on the two PGE-rich localities of the Shetland ophiolite, Cliff and Harold's Grave. Both are disused chromite quarries located in the north of the ophiolite and consist of several en echelon chromitite (also including chromite-rich lenses with $>10 \%$ chrome-spinel, normally $50-90 \%$ ) enclosed by a dunite envelope in mantle harzburgite. Cliff is near the basal thrust (Fig. 2) and has a dunite envelope smaller than Harold's Grave. Chromitite lenses at both localities are up to $10 \mathrm{~m}$ long and $1 \mathrm{~m}$ wide (Prichard et al., 1988). PGM in the Cliff and Harold's Grave chromitites are described in Prichard and Tarkian (1988) and Tarkian and Prichard (1987). These authors observed that IPGM are often enclosed in chromite whereas PPGE-bearing PGM occur within the serpentinised silicate matrix and are predominantly interstitial to the chromite grains.

PGM at Harold's Grave are dominated by laurite, ruthenian pentlandite, native Os and irarsite often rimmed by hollingworthite. Other minerals recorded include genkinite, hongshiite 
$129(\mathrm{PtCu})$, stibiopalladinite and unnamed $\mathrm{Rh}-\mathrm{Sb}-\mathrm{S}$ and $\mathrm{Rh}-\mathrm{Ni}-\mathrm{Sb}$ phases (Prichard and Tarkian,

130 1988). Recent studies reveal up to five generations of PGM in these chromitites (Prichard et

131 al., 2017). In contrast, the PGM in the rocks at Cliff are PPGM dominated. A PPGM

132 assemblage occurs in sulfide-bearing dunites adjacent to the chromitites which contain

133 IPGM. The very enriched PPGM-bearing dunite with disseminated chromite is thought to

134 have been hydrothermally upgraded during the introduction of $\mathrm{As}$ and $\mathrm{Sb}$, at a late stage as

135 the ophiolite was emplaced (Prichard and Lord, 1993; Lord et al., 1994). In this alteration

136 assemblage all six PGE form PGM in chromite-rich dunites at Cliff. The PGM consist of

137 sperrylite, Pd-antimonides, members of the irarsite-hollingworthite solid solution series, Pt-

138 Pd-Au-Cu alloys, laurite, native Os, potarite (PdHg) and Pt- and Pd-oxides, with PGM

139 diameters up to $30 \mu \mathrm{m}$, all accompanied by ruthenian pentlandite. Other studies have been

140 undertaken on the Cliff PGM as for example by Derbyshire et al. (2012) who located mainly

141 sperrylite.

143 The aim of this investigation was to examine the streams draining the Cliff and Harold's

144 Grave sites to characterise the placer PGM present and assess their genesis. The placer PGM

145 are compared to the primary PGM in the source rocks, and variations in the former with

146 increasing distance from the source rocks are also assessed. This study shows for the first

147 time the PGM in the streams draining the Shetland ophiolite and contributes to the increasing

148 knowledge base regarding whether alluvial PGM are mechanically eroded from their source

149 rocks, or whether they precipitate in situ as a result of chemical weathering.

\section{Methods}

152 A small network of streams with a maximum width of $0.5 \mathrm{~m}$ drains the ponds in the disused

153 chromite quarries at Cliff. These then coalesce to discharge into the Loch of Cliff, $400 \mathrm{~m}$ to 
154 the west of the Cliff quarries (Fig. 2). Rock samples were taken at the quarries and samples of 155 sediments were collected from the streams at four separate locations (Figs. 2 and 3; Table 1)

156 and panned on site in a plastic pool. Four samples (C2-C5) were taken from the first location,

157 at the commencement of the stream from the quarry pond. Sample C2 was taken at the

158 immediate exit of the pond whereas samples C3-C5 were within $5 \mathrm{~m}$ of the Cliff quarries. A

159 further four samples (C6-C9) were collected from the second location consisting of meanders

$16020-50 \mathrm{~m}$ downstream of the quarries. Another three samples (C10-C12) were taken

161 downstream within 20-30 m of the exit of the meander zone and after a moderate increase in

162 the slope gradient. Lastly, samples were collected from the stream as it plunged over the

163 basal thrust of the ophiolite (CS).

164

165 Sampling at Harold's Grave was conducted over a sloping E-W section spanning about $20 \mathrm{~m}$

166 along a stream draining outcrops of dunite cut by discontinuous layers of chromitite (Table

167 2). The section starts below a disused PGE-rich quarry and sampling included ten sites

168 separated by three natural ponds, the first two aligned at the beginning of the section and the

169 last one situated further down slope. The first five samples (HG1-HG5) were taken from the

170 entrance and exit of the first two ponds. This area is largely covered by vegetation; it has a 10

$171 \mathrm{~cm}$ topsoil with a high concentration of organic matter followed by a subsoil layer of

172 significantly weathered rock. The soil produced negligible heavy concentrates and holes were

173 excavated to a depth of $15-20 \mathrm{~cm}$ to obtain samples. The next four samples (HG6-HG9)

174 were collected from a site with more outcrop of fractured dunite following a strong break of

175 slope with increasing gradient. The last sample (HG10) was taken from the exit of the most

176 distal pond, where the soil layer becomes thicker again. Overall, the dense fraction recovered

177 from sampling sites at Harold's Grave was much smaller than that recovered from Cliff.

178 
179 Panned size fractions below $150 \mu \mathrm{m}$ were examined for precious metal minerals and PGM

180 using a Cambridge Instruments (ZEISS NTS) S360 scanning electron microscope (SEM),

181 coupled to an Oxford Instruments INCA energy plus energy dispersive X-ray analytical

182 system (EDX) at Cardiff University. Qualitative analyses were obtained of the mineral

183 surfaces, and polished blocks were utilized for fully quantitative analyses (Table 3).

184 Operating conditions for the quantitative analyses consisted of a $20 \mathrm{kV}$ accelerating voltage,

$1851 \mathrm{nA}$ beam current and fixed beam size (approximately $10-15 \mathrm{~nm}$ ), with a live-time of $50 \mathrm{~s}$

186 for EDX. A cobalt reference standard was regularly analyzed, in order to check for any drift

187 in the analytical conditions. A comprehensive set of standards obtained from MicroAnalysis

188 Consultants Ltd. (St Ives, Cambridgeshire) was used to calibrate the EDX analyzer.

190 Results

191 Alluvial PGM at Cliff

192 A total of 108 PGM and 8 grains of gold have been identified in samples C3-C11 and CS

193 collected from the streams at Cliff (Fig. 4a, Table 1). The PGM assemblage consists mainly

194 of sperrylite (69 grains; 64\% abundance), Pd-antimonides (18 grains; 17\%) and members of

195 the irarsite-hollingworthite solid-solution series (11 grains; 11\%). Less abundant phases are

196 Pd-sulfides (4 grains; 4\%), and Pt-alloys, Pd-arsenide and laurite (6 grains in total; 6\%).

197 These PGM range in size from 8-110 $\mu \mathrm{m}$ and consist of single minerals as well as composite

198 grains. The placer PGM reflect those observed in the source rocks, but exhibit less variety

199 (Fig. 4a, Table 1). Quantitative analyses of polished surfaces of the typical PGM have been

200 completed (Table 3).

201

202 Alluvial PGM in the streams at Cliff occur only within the first 100-150 $\mathrm{m}$ from the disused

203 quarries (Fig. 2; Fig. 4b). Of the 108 PGM grains recovered, 22\% are from the exit of the 
main pond close to the quarries, $58 \%$ are from the meander zone about $50 \mathrm{~m}$ away from the quarries, and 19\% come from downstream of the meander exit, about $100 \mathrm{~m}$ away. However, only one PGM grain was recovered further downstream, where the stream plunges over the basal thrust. The type, abundance and size of the alluvial PGM do not vary significantly downstream (Table 1, Fig. 4b). Sperrylite, Pd-antimonides and sulfarsenides together with Ptalloys and gold occur all along the stream. Pd-sulfides and -arsenides persist closer to the

210 quarries but are not present downstream and laurite, although scarce, appears furthest from 211 the source (Fig. 4b). The main PGM recovered from the streams at Cliff are described next.

Sperrylite is the most abundant PGM in the streams draining Cliff. It is commonly euhedral to subhedral and occurs in single cubes, octahedrons or aggregates of cubes that are

216 more or less abraded. Single grains range in size from 15 to $110 \mu \mathrm{m}$ and aggregates reach up to $100 \mu \mathrm{m}$ across.

Angular sperrylite is more common close to the Cliff quarries (Fig. 5). This sperrylite is often cracked, with pits and furrows on the surface. It occasionally shows surface structures that may correspond to a cleavage (Fig. 5a-c) and it can occur intergrown with silicates preserved

222 from the host rock (Fig. 5d-e), possibly chlorite or serpentine. Many grains of sperrylite show

223 a more jagged and altered appearance with extensive pitting of the mineral surfaces (Fig. 5f-

224 i). Grains or aggregates of euhedral sperrylite show more abraded edges with increasing 225 distance from the quarries (Fig. 5j-1). In fact, about $40 \%$ of the sperrylite grains recovered

226 from the streams are subhedral to subrounded (Fig. 6a-l) and occur mainly downstream, 227 further from the quarries. 
229 Sperrylite forms composite grains with irarsite (Fig. 7a-b) and Pd-antimonides (Fig. 7c-d). It

230 also occurs with laurite (Fig. 7e) and with the only grain of Pd-arsenide identified (Fig. 7f),

231 which attains a composition close to $(\mathrm{Pd}, \mathrm{Fe}, \mathrm{Ni})_{2}(\mathrm{As}, \mathrm{S})$. Polished sections of sperrylite reveal

232 other mineral associations (Fig. 8). These include: (i) Pt-alloys of the tetraferroplatinum type

233 (PtFe) in elongate grains $40 \mu \mathrm{m}$ across that are enclosed in broken sperrylite (Fig. 8a); (ii)

234 ruarsite (RuAsS) at the contact between sperrylite and stibiopalladinite (Fig. 8b); (iii)

235 platarsite (PtAsS) on the edge of abraded sperrylite (Fig. 8c); and (iv) Ni-sulfides and -

236 arsenides (millerite $(\mathrm{NiS})$ - godlevskite $\left(\mathrm{Ni}_{9} \mathrm{~S}_{8}\right)$ and nickeline (NiAs), which occur as

237 euhedral or elongated inclusions less than $10 \mu \mathrm{m}$ long within sperrylite (Fig. 8d).

238

239 Sperrylite has a regular PtAs 2 composition throughout the streams. Occasionally Rh (up to 9

240 wt.\%), and minor amounts of $\mathrm{Ru}, \mathrm{Pd}, \mathrm{Fe}$ or $\mathrm{Cu}(\leq 2 \mathrm{wt} . \%$ each $)$ have been detected.

241 Antimony and S ( $\leq 4$ wt.\% each) can replace As (Table 3$)$. This composition is similar to that

242 of sperrylite in the source chromitites, which contain lower but regular $\mathrm{Fe}(<0.5$ wt.\%) and $\mathrm{Sb}$

243 concentrations ( $\leq 3$ wt.\%) (Prichard and Tarkian, 1988).

\section{Palladium antimonides}

Palladium antimonides are the next most abundant PGM. The size of these PGM ranges from 20 to $105 \mu \mathrm{m}$ in diameter. They are more altered than the sperrylites in the streams and only $23 \%$ of the grains recovered preserve a euhedral shape (Fig. 9a). This occurs normally close to the quarries, where grains are often broken (Fig. 9b-c). Within the meander zone, all the grains show a characteristic fine striation on their surfaces (Fig. 7c; Fig.

$2519 \mathrm{~d}-\mathrm{g}$ ) denoting a lower resistance in the stream compared to sperrylite. The group of grains

252 located at the exit of the meander zone all show an etched appearance (Fig. 9h-i). Polished

253 sections of Pd-antimonide grains are smooth and internal inclusions are not observed. They 
typically exhibit homogeneous cores surrounded by an external rim of dismembered Pdantimonide. Internal fractures are also common (Fig. 8b).

256

257 Pd-antimonides often form composite grains with sperrylite (Fig. 7c-d, Fig. 8b), Pd-sulfides

258 (Fig. 9a), and Pt-alloys consisting of Pt-Pd-Cu (Fig. 9c) and PtFe (Fig. 9e). The latter is a

259 tetraferroplatinum included within a Pd-antimonide grain (Fig. 9e). In some cases, Pd-

260 antimonide occurs with electrum (e.g. Fig. 9d) which forms a thin cover along the surface

261 structures of the PGM.

262

263 Alluvial Pd-antimonides attain a composition that resembles stibiopalladinite $\left(\mathrm{Pd}_{31} \mathrm{Sb}_{12}-\right.$

$264 \mathrm{Pd}_{5+\mathrm{x}} \mathrm{Sb}_{2-\mathrm{x}}$, where $\left.\mathrm{x}=0.04\right)$ with some compositions extending towards $\mathrm{Pd}_{5} \mathrm{Sb}_{3}$, according to

265 ideal Pd-Sb phases of the Pd-Sb-Te system reported by Kim and Chao (1991) (Fig. 10a).

266 Analyses of Pd-antimonides yield elevated $\mathrm{Cu}$ contents for most of the analyzed grains (0-5

267 wt.\% Cu; av. 2.7 wt.\%), occasional contents of $\mathrm{As}(\leq 3.5$ wt.\%) and $\mathrm{Ni}(\leq 0.7$ wt.\%), and

268 rare $\mathrm{Fe}(\leq 2.7$ wt.\%) (Table 3). No other PGE have been recorded other than Pt. Similar

269 compositions are reported for Pd-antimonides in the host rocks at Cliff (mertieite II -

270 stibiopalladinite, Fig. 10a), although these contain more Pd, and some Pt up to 0.8 wt.\%

271 (Prichard and Tarkian, 1988).

Sulfarsenides

End and intermediate members of the irarsite-hollingworthite-platarsite solid solution series have been located throughout the streams draining Cliff.

276

277 Irarsite is the most abundant phase ( $\mathrm{n}=6$ grains) and occurs in single or composite grains and 278 aggregates with sizes ranging from 30 to $84 \mu \mathrm{m}$ in diameter. Irarsite in composite grains can 
279 be euhedral (Fig. 7a-b) and aggregates with etched surfaces also preserve the euhedral shape

280 of the grains (Fig. 11a). More often irarsite occurs as subhedral, etched grains (Fig. 11b-c). In

281 two cases it forms composite grains with sperrylite (Fig. 7a-b) and in one case with

282 hollingworthite (Fig. 11c). Alluvial irarsite shows two compositional trends, one with

283 increasing Rh content and the other with increasing Pt content (Fig. 10b). Normally, irarsite

284 attains a (Ir,Rh)AsS composition, with average Rh contents of about 7 wt.\% (Table 3). Some

$285 \mathrm{Sb}$ is also detected $(<1.5 \mathrm{wt} . \%)$. Less often, irarsite contains elevated Pt up to $22 \mathrm{wt} . \%$ and

286 Ru up to $10 \mathrm{wt. \%}$. Iridium-end members have not been located in the streams although they

287 are present in the rocks from Cliff (Tarkian and Prichard, 1987; Fig. 10b). Exceptionally, one

288 grain of platarsite (PtAsS) and another of ruarsite (RuAsS) have been located in polished

289 sections of the alluvial PGM. Platarsite occurs on the edge of a sperrylite grain (Fig. 8c,

290 Table 3). Ruarsite is in a polyphase grain with sperrylite and Pd-antimonide and contains

291 elevated Os up to 37 wt.\% (Fig. 8b, Table 3). It is of note that irarsite in the rocks from Cliff

292 is unusually Pt poor (Prichard and Tarkian, 1988) whereas Pt-bearing irarsite is observed in

293 the streams (Fig. 10b).

294

295 Hollingworthite occurs as subhedral grains $(\mathrm{n}=5)$ with sizes from 10 to $80 \mu \mathrm{m}$ across (Fig.

296 11c-f). Two of these are single grains (e.g. Fig. 11d) and the other three form composite

297 grains with irarsite (Fig. 11c), Pd-antimonide (Fig. 11e) or gold (Fig. 11f). One grain was

298 identified as end member hollingworthite (RhAsS, Fig. 11d) whereas the others contain Pt ( $\leq$

$2996 \mathrm{wt} . \%$ ) and rarely Ir or Os up to $11 \mathrm{wt} . \%$ and $6 \mathrm{wt} . \%$, respectively. Similarly to irarsite,

300 hollingworthite contains more Pt in the placers than in the source rocks (Fig. 10b).

301

302

Less abundant PGM 
304 close to the disused quarries at $\mathrm{Cliff}$ ( $\mathrm{n}=2$ grains, Fig. 9a) and as single, broken grains $10-70$

$305 \mu \mathrm{m}$ long in the meander zone. The two grains close to the quarries resemble vasilite in

306 composition $(\mathrm{Pd}, \mathrm{Fe}, \mathrm{Cu})_{16}(\mathrm{~S}, \mathrm{As}, \mathrm{Sb})_{7}$ and the grains in the meander resemble vysotskite

307 (Pd, Fe, Ni) (S, As) with low $\mathrm{Fe}$ and $\mathrm{Ni}$ contents (0-7 wt.\% in total).

309 Pt-alloys ( $\mathrm{n}=3$ grains) are different from each other in texture, composition and location along

310 the stream. One grain close to the quarries is a relict euhedral Pt-Pd-Cu alloy

$311\left(\mathrm{Pt}_{0.78} \mathrm{Pd}_{0.15} \mathrm{Cu}_{0.07}\right), 20 \mu \mathrm{m}$ across, that occurs in a composite grain with a broken $\mathrm{Pd}-$

312 antimonide (Fig. 9c). The second grain is a $50 \mu \mathrm{m}$ long tetraferroplatinum $\left(\mathrm{Pt}_{1.05}\right.$

$\left.313(\mathrm{Fe}, \mathrm{Ni}, \mathrm{Cu})_{0.95}\right)$ included in a wrinkled Pd-antimonide from the meander zone (Fig. 9e).

314 Another particle of similar composition was also located enclosed by sperrylite in polished

315 sections (Fig. 8a). The third grain is a subrounded, single tetraferroplatinum $\left(\mathrm{Pt}_{2.7}\right.$

$\left.316(\mathrm{Fe}, \mathrm{Cu}, \mathrm{Ni})_{1.3}\right), 60 \mu \mathrm{m}$ across, that contains lower $\mathrm{Ni}$ and $\mathrm{Cu}$ totaling $<5$ wt.\%. This last grain

317 belongs to sample C10, downstream, after the meander area. Only one analysis of a $5 \mu \mathrm{m}$

318 sized Pt-Pd-Cu-Sb alloy from the source chromitites is available in the bibliography (Prichard

319 and Tarkian, 1988) and comparatively, the alluvial Pt-Pd-Cu alloy found is larger and

320 contains more Pt and less Pd (Fig. 10a).

322 Laurite ( $\mathrm{n}=2$ grains) is rare in the alluvial assemblage. One grain with Pd-antimonide (Fig.

$3237 \mathrm{e}$ ) in the meander is euhedral and has a pure composition of $\mathrm{RuS}_{2}$. The other grain is the

324 only PGM recovered from sample site CS (Fig. 2), the furthest from the Cliff quarries. This is

325 a subhedral single grain with a composition similar to (Ru,Os) (S,As), with up to 14 wt.\% Os.

326 The presence of both Os-Ir-bearing laurite and Os-free laurite with inclusions of native Os

327 was also noted in the source rocks (Tarkian and Prichard, 1987; Fig. 10b). Much of this Os is 
328 likely to be derived from the alteration of Os-laurite to pure $\mathrm{RuS}_{2}$ during serpentinization of

329 the ophiolite (Prichard et al., 2017). Both types of laurite remain in the placers.

330

331 Other less abundant PGM in the placers include one grain of palladoarsenide (Fig. 7f), and

332 one grain of ruarsite and another of platarsite (Fig. 8b-c) found only in the polished sections

333 of the alluvial PGM.

Gold

Eight Au-bearing grains from 30 to $80 \mu \mathrm{m}$ in diameter have been identified. Five of

337 these occur as single particles of electrum with up to $25 \mathrm{wt} . \% \mathrm{Ag}$ (Table 3). Only one

338 irregular grain of electrum was recovered close to the Cliff quarries (Fig. 12a). Electrum in

339 the meander zone occurs as subhedral pitted grains (Fig. 12b), round smooth grains (Fig. 12c)

340 and as a porous grain with a delicate structure (Fig. 12d). Gold-bearing phases also occur as

341 thin covers on the surfaces of PGM and Au. For example, pitted electrum is observed on the

342 surface of a Pd-antimonide (Fig. 9d) and pitted Au-(Cu-Pt-Pd) occurs on the surface of a

343 composite grain of hollingworthite and Au (Fig. 11f). Downstream, a Au-Pd cover with up to

3442.6 wt.\% Pd was observed on a composite grain of Pd-antimonide and sperrylite. Some placer

345 gold particles at Cliff (Fig. 12a-d) mimic the textures of the gold grains located in the source

346 rocks, where rounded and porous particles were detected (Fig. 13a-b).

348 Alluvial PGM at Harold's Grave

349 The results from panning at Harold's Grave were less successful and the source rocks here are

350 dominated by IPGM (Table 2). PGM and gold were recovered from samples HG1, 2, 7 and

35110 (Table 2), so they are erratically distributed though the sampling sites. One euhedral

352 composite grain of $40 \mu \mathrm{m}$ laurite $\left(\mathrm{Ru}_{0.98} \mathrm{~S}_{2.02}\right)$ with iridium (Ir-Fe-(S,As)), as well as one 60 
$353 \mu \mathrm{m}$ grain of osmium $\left(\mathrm{Os}_{0.9} \mathrm{Ir}_{0.06} \mathrm{Ru}_{0.04}\right)$ with subhedral shape and pitted edges were recovered

354 from the panned material.

355

356 In addition, four Au grains up to 300x400 $\mu \mathrm{m}$ in size were also recovered. They are all

357 relatively pure in terms of composition. Two grains of $\mathrm{Au}$, both with minor contents of $\mathrm{Cu}$

358 (4-17 wt.\%), exhibit the same fine porous texture on their surfaces, although one is euhedral

359 and the other is subrounded. The other two grains (Fig. 12e-f) are subhedral and very porous

360 aggregates. They consist of subrounded particles of Au with minor amounts of Ag in

361 composition (6 wt.\% on average) and show formations of pure dendritic Au on their surfaces.

362

363 Discussion

364 Examination of the placer PGM derived from the Shetland PGE-rich chromitites at Cliff and

365 Harold's Grave allows for the comparison between PGM assemblages in the source rocks and

366 streams in order to identify the most relevant modifications of the alluvial minerals and asses

367 their origin.

368

369 Evolution of placer PGM from the rocks

370 The source rock PGM assemblage is represented by those listed in Tarkian and Prichard

371 (1987) and Prichard and Tarkian (1988), and it is also described in Prichard et al. (1986;

372 1988; 1994; 2017). Estimation of the percentages of each type of PGM given in Tables 1 and

373 2, and in Fig. 4a, is illustrative and for comparison purposes only. Prichard et al. (1994) also

374 observed oxidised Pt and Pd phases in the chromite-rich rocks at Cliff. More recently, an

375 extensive study of the PGM was carried out to find Os-bearing minerals for Os isotope

376 analysis (e.g. Prichard et al., 2017). This revealed, in addition to those PGM already

377 described, significant oxidation of the PGM including oxidised Pt-Pd-Ni-Cu-alloys and 
378 sperrylite. One grain of $\mathrm{Pd}-\mathrm{O}, 60 \mu \mathrm{m}$ in diameter, was also located. There is also the

379 occurrence of breithauptite ( $\mathrm{NiSb}$ ) containing approximately $1 \% \mathrm{Pd}$ as well as geversite

$380\left(\mathrm{PtSb}_{2}\right), \mathrm{Pt}-\mathrm{Fe}$ alloy and one Pd-Te-Sb-Bi (Fig. 13c-f). In the more recent survey it became

381 clear that many of the laurite and clusters of PPGM grains have sizes in the rocks of 30-40

$382 \mu \mathrm{m}$, reaching up to $60 \mu \mathrm{m}$.

383

The placer PGM assemblage recovered at Cliff reflects the type and abundance of those PGM in the rocks but there is less variety in the alluvial concentrates (Fig. 4a). Alluvial PGM are equally dominated by sperrylite, Pd-antimonides and sulfarsenides. In addition, Pdsulfides, Pd-arsenide, platarsite and ruarsite (totalling 8 grains only) were also recovered from the streams. Millerite and nickeline are barren of PGE and occur only as internal inclusions in sperrylite. Scarce Pt-alloys (Pt-Pd-Cu, Pt-Fe) and laurite complete the alluvial PGM assemblage. Electrum and Cu-Pt- and Pd-bearing gold also occur as both single grains and coatings on detrital PGM. Alluvial PGM and associated gold have average sizes of $21 \times 76$ $\mu \mathrm{m}$, and range from 5 to $110 \mu \mathrm{m}$ in diameter.

Compared with the source rocks, there is a clear increase in sperrylite $(>24 \%)$ and decrease in stibiopalladinite $(<10 \%)$, irarsite and hollingworthite $(<7 \%)$, and Pt-alloys $(<2 \%)$ in the streams. Composite PGM of sperrylite with Pd-antimonide, irarsite and laurite occur in both the source rocks and placers. Laurite is equally scarce in rocks and streams (Fig. 4). The least abundant PGM in the rocks such as native $\mathrm{Os}, \mathrm{Rh}-\mathrm{Sb}-\mathrm{S}$, geversite $\left(\mathrm{PtSb}_{2}\right)$, potarite $(\mathrm{PdHg})$ or rare Pd-Te phases are absent in the streams. Nickel- and $\mathrm{Cu}$-bearing phases in the rocks such

401 as ruthenian pentlandite, hongshiite $(\mathrm{PtCu}), \mathrm{Ni}-\mathrm{Cu}$ alloys, and native $\mathrm{Cu}$, have not been 
402 located in the alluvial concentrates either. Likewise, oxidised Pt- and Pd-phases are absent in 403 the streams.

405 The composition of the common PGM between rocks and streams is rather similar, although

406 some alluvial PGM such as irarsite, hollingworthite and Pt-alloys exhibit increase Pt contents

407 while alluvial $\mathrm{Pd}$-antimonides show a progressive loss of $\mathrm{Pd}$. Increased $\mathrm{Rh}$ content is also

408 observed in alluvial irarsite (Fig. 10a, b). Gold-bearing particles have a similar composition

409 (Au-Pd, $\mathrm{Au}-\mathrm{Cu}-\mathrm{Pt}$ ), although electrum dominates the alluvial assemblage.

410

411 Placer PGM are mainly concentrated where the stream meanders have formed, from which $41258 \%$ of the PGM found were recovered (Fig. 4b). Only one grain of laurite was located

413 towards the basal thrust. At this point the slope gradient and the water flow are intense,

414 forming a waterfall under which loose sediment is deposited (Fig. 3e) and where a greater 415 accumulation of heavy minerals is expected. Thus, it is clear that a great part of the alluvial 416 PGM has been concentrated close to the quarries, particularly in the suitable meander zone, 417 but PGM have not been able to travel further downstream.

419 The types of placer PGM do not vary significantly downstream. The most abundant PGM 420 persist throughout the stream and have similar sizes. However, the shape of the alluvial PGM 421 does vary and the PGM often show signs of disintegration downstream. Sperrylite and Pd422 antimonides exhibit these variations most clearly as they are the most common PGM 423 observed. Sperrylite, where it occurs close to the source rocks, retains its euhedral and 424 angular form (Fig. 5) whereas further downstream it shows smoother surfaces and becomes 425 progressively more rounded (Fig. 6). Pd-antimonides, where they are observed close to the 426 quarries, are subhedral and have silicates attached to their surfaces whereas in the meander 
zone, these silicates are absent and the PGM may show lamellar structures. Further

428 downstream, etching of Pd-antimonides is common in the form of concave faces or irregular surfaces (Fig. 9). The same is observed for Pd-sulfides, which are euhedral close to the quarries but appear broken down in the meander zone. Also for Pt-alloys, which are enclosed

431 by other PGM close to the source rocks but appear as single, subrounded Pt-Fe particles 432 downstream.

\section{Harold's Grave}

At Harold's Grave, PGM are dominated by IPGM (Tarkian and Prichard 1987;

Prichard et al., 1988, 2017). The IPGM assemblage in the rocks (Table 2) consists of laurite, osmium, irarsite and IrSbS. The size of the IPGM in the rocks ranges from a few microns to $500 \mu \mathrm{m}$, as found by Badanina et al. $(2013,2016)$ from concentrates of the rocks produced using the hydroseparation technique, and by Prichard et al. (2017) using 3D X-ray tomography. The PPGM are hollingworthite and scarce hongshiite (PtCu), Pt-alloy (Pt-Pd-

$441 \mathrm{Cu})$, genkinite and Pd-, Rh- and Ni-bearing antimonides totalling 9 grains only $(<10 \%$; Table 2). The survey by Prichard et al. (2017) corroborates that PPGM, including minor sperrylite,

443 Pt-Fe alloys and platarsite, typically occur in clusters with Ru-pentlandite and some IPGM 444 interstitially to chromite grains.

446 The placer PGM located at Harold's Grave ( $\mathrm{n}=3$ grains) consist of laurite, iridium alloy and 447 osmium alloy, with sizes ranging from 20 to $60 \mu \mathrm{m}$. No PPGM or pentlandite were recovered 448 (Table 2). Despite the scarce PGM recovered, these represent the most abundant PGM in the 449 IPGE-rich chromitites at Harold's Grave. The presence of gold is noteworthy. Detrital grains 450 of $\mathrm{Au}-\mathrm{Cu}$ have been detected but electrum and native Au also occur in porous aggregates up 451 to $400 \mu \mathrm{m}$ across with dendritic growths of native Au on surface. The sizes of the alluvial 
452 PGM and Au at Harold's Grave are in the range of those in the source rocks. No other

453 statistically significant conclusions can be drawn due the low recovery of placer PGM in the 454 panned samples.

455

Overall, only slight differences are observed between the PGM assemblages of the rocks and streams:

459 (i) Those PGM enclosed by or in the edges of chromite grains in the source rocks are poorly represented or absent in the streams, suggesting that they may remain protected by their host

461 minerals in the alluvial sands. This is mainly the case for Ru- and Os-PGM (laurite, osmium) 462 within chromite grains in the rocks. Potarite (PdHg) also occurs in chromite, and antimonides

463 (RhSbS, IrSbS, Rh-Ni-Sb, NiSb, Pd-Cu-Sb and genkinite) are often located in clusters within 464 irarsite (Tarkian and Prichard, 1987; Prichard and Tarkian, 1988). The lack of these PGM in 465 the streams is more evident at Harold's Grave, where the source chromitites are IPGE466 enriched. In this case, however, the small dense fraction recovered may reflect lower erosion 467 and a more restricted liberation of the host minerals and PGM into the streams.

469 (ii) PGM that occur in the silicate matrix interstitial to chromite grains in the rocks, less 470 protected against weathering, are largely represented in the streams at Cliff. These are 471 sperrylite, stibiopalladinite, irarsite-hollingworthite-platarsite and Pt-alloys. Of these, 472 sperrylite is the most resistant whereas Pd-, Ir-and Rh-PGM decrease in number and show 473 slight changes in their composition (Figs. 4, 10). Their abundance and composition suggest 474 some progressive Pd-loss and Pt-gain in the streams. For example, alluvial stibiopalladinite 475 grains extend towards $\mathrm{Pd}_{5} \mathrm{Sb}_{3}$ compositions and show a loss of up to $14 \mathrm{wt} . \% \mathrm{Pd}$. The alluvial 476 Pt-Pd-Cu alloy contains less $\mathrm{Pd}(<8$ wt.\%) and more Pt $(>25 \mathrm{wt} . \%)$ than its counterpart in the 
rocks, and isoferroplatinum $\left(\mathrm{Pt}_{3} \mathrm{Fe}\right)$ only occurs in the streams. Irarsite and hollingworthite also contain more $\mathrm{Pt}(>4 \%)$ in the streams than in the rocks (Fig. 10b).

(iii) There are some losses of PGE-bearing phases from the rock assemblage into the streams.

The most notable of these is the loss of all $\mathrm{Pt}$ and $\mathrm{Pd}$ oxides, which are poorly resistant compounds typically on the edges of broken PGM (Fig. 13d-e) that are not preserved during the transportation process. The disappearance of PGE-oxides or -hydroxides from source rocks in the fluvial environment has been previously reported from rivers draining the Great Dyke in Zimbawbe (Oberthür et al., 2003, 2013) and the Freetown layered complex in Sierra Leone (Bowles et al., 2017a, 2017b). Bowles et al. (2017b) also noted the low stability of Cubearing sulfides and $\mathrm{PGM}$ such as tulameenite $\left(\mathrm{Pt}_{2} \mathrm{FeCu}\right)$ during weathering of the rocks.

The low stability of $\mathrm{Cu}$ - and also Ni-bearing phases is also inferred from the eroded chromitites at the Shetland complex, as most of them (e.g. Ru-pentlandite, hongshiite PtCu, and $\mathrm{Cu}$-bearing alloys) are largely absent in the streams. All these phases occur in interstitial positions to chromite grains in the rocks. For example, hongshiite occurs at the edge of sperrylite and intergrown with Ni-Cu alloys, while $\mathrm{Pt}-\mathrm{Pd}-\mathrm{Au}-\mathrm{Cu}$ and $\mathrm{Pd}-\mathrm{Cu}$ alloys occur in composite grains with native $\mathrm{Cu}$ (Tarkian and Prichard, 1987; Prichard and Tarkian, 1988). Of all these, only sperrylite and one Pt-Pd-Cu alloy in stibiopalladinite remain in the streams.

496 It is worth noting that $\mathrm{Cu}$-bearing phases are scarce in the source rocks (Table 2) and some of them could have been missed during preparation of the panned samples. However, Ni- and

$498 \mathrm{Cu}$-intermetallic compounds and sulfides, and moreover pentlandite, are highly unstable 499 phases in supergene conditions, and $\mathrm{Ni}$ and $\mathrm{Cu}$ can be lixiviated in a wide range of oxidizing 500 Eh and acid to neutral pH conditions (Garrels and Christ, 1965; Williams, 1990; Takeno, 
501 2005). Thus, Cu-bearing PGM from the Shetlands chromitites, if not protected by their host

502 (e.g. Fig. 8a, d; Fig. 9e), may have been destroyed during weathering.

504 (iv) The textures and composition of the gold grains $(\mathrm{Au}-\mathrm{Pd}, \mathrm{Au}-\mathrm{Cu})$ in the rocks almost

505 exactly mimic those in the placers with both rounded grains and spongy textured grains

506 observed (Fig. 13a-b). They are clearly an integral part of the precious metal occurrence at

507 Cliff as they are located in the rocks and have not been derived from carriage by say boulder

508 clay from outside the area. Only dendritic growths of pure $\mathrm{Au}$ over $\mathrm{Au}-(\mathrm{Ag})$ grains at

509 Harold's Grave may reflect some remobilization of Au at the grain scale (Fig. 12e-f). These

510 particles satisfy the model for secondary Au formation described in Hough et al. (2011),

511 which integrates a primary origin of the Au grains with secondary mobilization and

512 aggregation processes on grains surfaces. This secondary Au typically displays high purity,

513 very fine crystallinity, and a wide variety of morphologies, resulting from $\mathrm{Au} / \mathrm{Ag}$ dissolution

514 and Au precipitation acting simultaneously on the surface of the grains.

516 Although it is difficult to evaluate the metal mobility based on mineralogical observations

517 alone, these data suggest that there is a preferential mobility of $\mathrm{Pd}, \mathrm{Cu}, \mathrm{Ni}$ and some $\mathrm{Au}$ over

518 other metals (i.e. Pt, Rh, Ir, Os, Ru) in the secondary environment of the Shetland ophiolite 519 complex.

521 Origin of the PGM

522 The overall similarity of the PGM assemblages of the PGE-rich rocks and the associated

523 streams suggests that the PGM have weathered from the rock and their short transport

524 distances have allowed them to preserve largely their compositions and often euhedral

525 shapes. There are some losses from the rock assemblage, but the PGM assemblage in the 
526 rocks is very similar to that in the streams. The PGM in the streams are of a similar size to the

527 larger PGM in the rocks reflecting a mechanical transportation process rather than a growth

528 in situ of the PGM. This suggests early stages of dispersal of the PGE from the quarries.

530 The long standing debate concerning the mechanical erosion of PGM from the source rocks

531 versus the growth of PGM in situ downstream of the source has been a point of controversy

532 for years. The sometimes contrasting mineralogical assemblages and PGM composition

533 between sources and placers, the delicate morphologies and larger size of placer nuggets

534 compared to primary PGM in the rocks or their isotopic signatures, all have been used in

535 discussion to support both models.

536

537 It is considered that placer PGM are normally primary and are mechanically eroded from the

538 source rocks (e.g. Cabri et al., 1996; Weiser, 2002; and references therein). In some

539 complexes they may indeed be large PGM that are simply eroded from the rocks, as for

540 example in some Ural-Alaskan type complexes. Some large PGM have been located in lode

541 placers from the Nizhni Tagil and Kachkanar dunite massifs in the Uranium Platinum Belt, in

542 the Vetnaya-Vyvenka Belt of Kamchatka, Russian Far East, or in the dunite core of the Pt-

543 rich Alto Condoto Complex in Colombia (Weiser, 2002 and references therein). Rare, large

544 PGM also occur in the oxidized Main Sulfide Zone of the Great Dyke, Zimbabwe (Oberthür

545 et al., 2003) and also in the Shetland chromitites (Badanina et al., 2013).

546

547 Doubt was cast when Ottemann and Augustithis (1967) proposed that polyphase Pt-Fe

548 nuggets in a laterite capping the massif of Yubdo (Ethiopia) formed at low temperatures by

549 'element agglutination'. Later, it was proposed that weathering of the rocks aided by organic

550 acids in the soils alter and break down primary PGM liberating the PGE, which can be 
transported in solution through the soils down slope. Soils close to rivers or stream banks

552 where Eh and $\mathrm{pH}$ conditions change allow for the precipitation of the PGE and the growth of

553 PGM (Bowles, 1986; 1988; Bowles et al., 1994a, 1994b, 1995). Selective metal leaching

554 during weathering to form supergene PGM has been documented for the perfectly

555 crystallized eluvial and alluvial PGM from the Freetown Igneous Complex, Sierra Leone

556 (e.g. Bowles 1995; Bowles et al., 2013, 2017a, 2017b). Also for the oxidized Main Sulfide

557 Zone of the Great Dyke, Zimbabwe and associated Pt-dominated alluvials (Oberthür et al.,

558 2003), as well as for the botryoidal and arborescent Pt-Pd aggregates and the Pt-enriched rims

559 on detrital PGE-alloys from the Bom Succeso stream in Minas Gerais, Brazil (Cabral et al.,

$5602007,2009)$.

561

562 There are many other examples of PGE-bearing phases that apparently formed in low

563 temperature conditions $\left(\sim 100-25^{\circ} \mathrm{C}\right)$ in varied deposits. One example are the internally zoned

564 Au-Pd arborescent grains from Hope's Nose, UK (Leake et al., 1991) and Serra do

565 Espinhaço, Minas Gerais (Cabral et al., 2008). Another example are the rosettes of native Pd

566 on the surface of gold nuggets from Gongo Soco Fe-ores, Minas Gerais (Cabral and Kwitko-

567 Ribeiro, 2004) and the Pd-Cu rosettes coating goethite in the Limoeiro Ni-Cu-(PGE) deposit

568 (Mota-e-Silva et al., 2016). Neoformed Pt-Ir-Fe-Ni alloys and layers of Ir-rich alloys on

569 multistage PGE-grains are reported from Ni-laterites in the Falcondo mining area (Dominican

570 Republic, Aiglsperger et al., 2016). It appears that supergene precipitation of PGE could be

571 aided by both biogenic activity (Reith et al., 2016; Bowles et al., 2017b) and inorganic

572 processes such as bioreduction or electrochemical accretion of metals (e.g. Cabral et al.,

573 2011; Aiglsperger et al., 2016).

574 
575 The resolution to this controversy may be partially explained in that both ideas are correct in

576 certain circumstances. Mechanical erosion may be more prominent in high latitudes where

577 mechanical erosion dominates over chemical weathering. However, in tropical conditions,

578 chemical weathering dominates and PGM may precipitate in situ, perhaps in soils or stream

579 banks distally to the source rocks following the chemical disintegration of the primary PGM.

580 Rock-weathering conditions in humid and temperate zones, with high rainfall and abundant

581 organic material would enhance PGE mobility and redeposition. It is clear that both primary

582 (magmatic or hydrothermally modified) PGM mechanically liberated from the rocks and

583 secondary, reworked or neoformed supergene PGE-bearing minerals, can coexist in some

584 eluvial and alluvial placers.

586 In the Shetland Islands mechanical erosion dominates and is operating only on a small scale

587 very close to the source. The PGM in the streams reflect the source rocks as they are very

588 close to them. There are signs of disintegration of the PGM as they travel downstream. Pd-

589 antimonides weather to produce furrowed surfaces and concave etched surfaces whereas

590 sperrylite starts with jagged edges that become rounded downstream. The greater initial

591 disintegration of Pd-bearing phases over sperrylite observed at Cliff may be a result of the

592 greater mobility of Pd over Pt which has been consistently observed, including in surficial

593 weathering environments (e.g. Fuchs and Rose, 1974; Wood and Vlassopoulos, 1990;

594 Prichard and Lord, 1994; Salpéteur et al., 1995; Prichard et al., 2001; Suárez et al. 2010,

595 Bowles et al., 2013). Sperrylite is harder than Pd-antimonides and has proved to be

596 considerably more durable and resistant to weathering and mechanical erosion (e.g., Oberthür

597 et al., 2003, 2013; Suárez et al., 2010), which also appears true in this study of placer PGM at

598 the Shetlands ophiolites. 


\section{Conclusions}

601 The PGM assemblage in the streams at Cliff consists dominantly of sperrylite and Pd-

602 antimonides and this is reflected by the PGM found in the rocks. The extreme proximity of

603 the source to the streams and the well documented PGM assemblage in the rocks allows a

604 comparison of PGM compositions and sizes in the rocks against those in the streams. This

605 reveals that the assemblages are very similar although there are notable absences of some

606 PGM types in the streams. The Pt and Pd oxides in the rocks are missing in the streams,

607 demonstrating that they are very fragile and unlikely to survive erosion. Ni-sulfides and $\mathrm{Cu}-$

608 bearing PGM and alloys are also unstable phases that remain in the streams only when

609 protected by their original host minerals. Thus there is a continuum from magmatic formation

610 and hydrothermal upgrading of the PGM assemblage in the rocks through to initial

611 weathering and oxidation of the PGM in the rocks through to erosion into the streams. Within

612 the streams there is further evidence of change in the PGM assemblage. More resistant

613 minerals such as sperrylite persist downstream becoming more rounded whereas Pd

614 antimonides can be observed in the early stages of disintegration with concave etching on

615 their surfaces. Laurite and members of the irarsite-hollingworthite-platarsite solid solution

616 series are also preserved in the streams. The common Pt-Fe alloys observed in many placer

617 deposits are largely absent. The gold grains in the streams are eroded from the Cliff

618 assemblage in the rocks as indicated by the close similarity of the textures that they show in

619 both the rocks and in the streams. The presence of $\mathrm{Au}-\mathrm{Pd}$ and $\mathrm{Au}-\mathrm{Cu}$ layers over primary

620 PGM and of native Au in dendritic growths may indicate a local remobilization of these

621 elements in surface conditions, at least on the grain scale. Otherwise the PGM assemblage

622 preserved in the streams at Cliff is early stage with PGM having been mechanically eroded

623 from the nearby source rocks and there is no evidence of growth in situ of PGM in the placers

624 rather mechanical disintegration. This is early stage mechanical erosion and so the usual Os- 
625 Ir-Ru alloys that characterises ophiolitic placer PGM are not present. This is more evident at

626 Harold's Grave, where the few IPGM found in the streams reflect the restricted release of the

627 PGM enclosed by primary minerals in the source rocks. In general, the alluvial PGM

628 assemblage found in the streams draining the Shetland complex mimics the rather unusual

629 suite of PGM in the PGE-rich ophiolitic rocks.

630

631 Acknowledgements

632 We would like to thank The Department of Education, Universities and Research of the

633 Basque Government (Refs. IT762-13, BFI-2011-254) for additional funding and Dr. R.S.

634 Garcia (UPV/EHU) for her technical support. We also thank the helpful comments by Dr. F.

635 Zaccarini and another anonymous referee, which greatly improved the quality of the

636 manuscript, and Drs. I. McDonald and B. O'Driscoll for the editorial handling. The coauthors

637 of this work are very grateful to D.R. Sharp, A. Colling and Dr. J.F.W. Bowles for their

638 contributions to this manuscript. We dedicate this work with all of our love to Prof. Hazel M.

639 Prichard and John S. Watson.

640

641 References

642 Aiglsperger, T., Proenza, J.A., Font-Bardia, M., Baurier-Aymat, S., Galí, S., Lewis, J.F. and

643 Longo, F. (2016). Supergene neoformation of Pt-Ir-Fe-Ni alloys: multistage grains

644 explain nugget formation in laterites. Mineralium Deposita, Published on-line 12

645 November 2016, https://doi.org/10.1007/s00126-016-0692-6.

646 Augé, T., Legendre, O. and Maurizot, P. (1998) The distribution of Pt and Ru-Os-Ir minerals

647 in the New Caledonia ophiolite. Pp. 141-154 in: International Platinum (P.N. Laverov

648 and V. V. Distler, editors). Theophrastus publications, St. Petersburg, Athens. 
649 Bacuta, G. C. J., Lipin, B. R., Gibbs, A. K. and Kay R.W. (1988) Platinum-group element 650 abundance in chromite deposits of the Acoje ophiolite block, Zambales ophiolite 651 complex, Philippines. Pp. 381-382 in: Geo-Platinum Symposium Volume (H. M.

652 Prichard, P. J. Potts, J. F. W. Bowles and S. J. Cribb, editors). Elsevier.

653 Badanina, I. Y., Malitch, K. N., Lord, R. A. and Meisel, T. C. (2013) Origin of primary

654 assemblage in chromitite from a mantle tectonite at Harold's Grave (Shetlan Ophiolite

655 Complex, Scotland). Mineralogy and Petrology, 107, 963-970.

656 Badanina I. Y., Malitch K. N., Lord R. A., Belousova E. A. and Meisel T. C. (2016) Closed-

657 system behaviour of the Re-Os isotope system recorded in primary and secondary

658 platinum-group mineral assemblages: evidence from a mantle chromitite at Harold's

659 Grave (Shetland Ophiolite Complex,Scotland). Ore Geology Reviews, 75, 174-185.

660 Bowles, J. F. W. (1986) The development of platinum-group minerals in laterites. Economic

$661 \quad$ Geology, 81, 1278-1285.

662 Bowles, J.F.W. (1988) Further studies of the development of platinum-group minerals in the 663 laterites of the Freetown Layered Complex, Sierra Leone. Pp. 273-280 in: Proceedings

664 of the symposium Geo-Platinum 87. (H.M. Prichard, P.J. Potts, J.F.W. Bowles and S.J.

665 Cribb, editors). Elsevier Applied Science, London.

666 Bowles, J. F. W. (1995) The development of platinum-group minerals (PGM) in laterites:

667 mineral morphology. Chronique de la Recherche Minière, 520, 55-63.

668 Bowles, J.F.W., Giże, A.P. and Cowden, A. (1994a) The mobility of the platinum-group

669 elements in the soils of the Freetown Peninsula, Sierra Leone. The Canadian

$670 \quad$ Mineralogist, 32, 957-967.

671 Bowles, J.F.W., Giże, A.P., Vaughan, D.J. and Norris, S.J. (1994b) The development of

672 platinum-group minerals in laterites; an initial comparison of the organic and inorganic 

Science, 103, 53-56.

675 Bowles, J.F.W., Giże, A.P., Vaughan, D.J. and Norris, S.J. (1995) Organic controls on

676 platinum-group element (PGE) solubility in soils: initial data. Chronique de la Recherche 677 Minière, 520, 65-73.

678 Bowles, J.F.W., Lyon, I.C., Saxton, J.M. and Vaughan, D.J. (2000) The origin of platinum 679 group minerals from the Freetown Intrusion, Sierra Leone, inferred from osmium isotope 680

Bowles, J.F.W., Prichard, H. M., Suárez, S. and Fisher, P.C. (2013) The first report of platinum-group minerals in magnetite-bearing gabbro, Freetown layered Complex, Sierra Leone: occurrences and genesis. The Canadian Mineralogist, 51, 455-473.

Bowles, J.F.W., Suárez, S., Prichard, H. M. and Fisher, P.C. (2017a) Weathering of PGE sulfides and Pt-Fe alloys in the Freetown Layered Complex, Sierra Leona. Mineralium Deposita. Published on-line 20 January 2017, https://doi.org/10.1007/s00126-0160706-4.

Bowles, J.F.W., Suárez, S., Prichard, H. M. and Fisher, P.C. (2017b) The mineralogy, 689 geochemistry and genesis of the alluvial platinum-group minerals of the Freetown Layered Complex, Sierra Leone. Mineralogical Magazine. Published on-line 19 June

Bridges, J. C., Prichard, H. M., Neary, C. R. and Meireles, C. A. (1993) Platinum-group 2017, https://doi.org/10.1180/minmag.2017.081.032. element mineralization in the chromite-rich rocks of the Braganca massif, northern Portugal. Transactions Institute Mining Metallurgy, B Applied Earth Science, 102,

696 Brough, C. P., Prichard, H. M., Neary, C. R., Fisher P. C. and McDonald, I. (2015) 

208.

Cabral, A.R. and Kwitko-Ribeiro, R. (2004) On the rossettes of "native palladium" from

Cabral, A.R., Tupinanbá, M., Lehmann, B., Kwitko-Ribeiro, R. and Vymazalová, A. (2008)

Cabral, A.R., Beaudoin, G., Choquette, M., Lehmann, B. and Polônia, J.C. (2007) Supergene Minas Gerais, Brazil: evidence from Gongo Soco. The Canadian Mineralogist, 42, $683-674$.

Cabral, A.R., Beaudoin, G., Choquette, M., Lehmann, B. and Polonia, J.C. (2007) Supergene leaching and formation of platinum in alluvium: evidence from Serro, Minas Gerais, Brazil. Mineralogy and Petrology, 90, 141-150. Arborescent palladiniferous gold and empirical $\mathrm{Au}_{2} \mathrm{Pd}$ and $\mathrm{Au}_{3} \mathrm{Pd}$ in alluvium from southern Serra do Espinhaço, Brazil. Neues Jahrbuch für Mineralogie Abhandlungen, 148/3, 329-336.

Cabral, A. R., Lehmann, B., Tupinambà, M., Schlosser, S., Kwitko-Ribeiro, R. and Abreu, F. R. (2009) The platiniferous Au-Pd belt of Minas Gerais, Brazil, and genesis of its botroidal Pt-Pd aggregates. Economic Geology, 104, 1265-1276.

Cabral, A. R., Radtke, M., Munnik, F., Lehmann, B., Reinholz, U., Riesemeier, H., Tupinambá, M. and Kwitko-Ribeiro, R. (2011) Iodine in alluvial platinum-palladium nuggets: Evidence for biogenic precious-metal fixation. Chemical Geology, 281, 125132.

Cabri, L. J. and Harris, D. C. (1975) Zoning of Os-Ir alloys and the relation of the geological and tectonic environment of the source rocks to the bulk Pt:Pt+Ir+Os ratio for placers. The Canadian Mineralogist, 13, 266-274.

Cabri, L. J., Harris, D. C. and Weiser, T. W. (1996) Mineralogy and petrology of platinumgroup mineral (PGM) placer deposits of the world. Exploration and Mining Geology, 5, $73-176$. 
723 Corrivaux, L. and Laflamme, J. H. G. (1990) Minéralogie des éléments du groupe du platine

724 dans les chromitites de l'ophiolite de Thetford mines, Québec. The Canadian

725 Mineralogist, 28, 579-595.

726 Derbyshire, E.J., O'Driscoll, B., Lenaz, R., Gertisser, R. and Kronz, A. (2012)

727 Compositionally heterogeneous podiform chromitite in the Shetland Ophiolite Complex

728 (Scotland): Implications for chromitite petrogenesis and late stage alteration in the

729 upper mantle portion of a supra-subduction zone ophiolite. Lithos, 162-163, 279-300.

730 Escayola M., Garuti D., Zaccarini F., Proenza J., Bédard J.H. and Van Staal, C. (2011)

731 Chromitite and Platinum-Group-Element Mineralization at Middle Arm Brook, Central

732 Advocate Ophiolite Complex, Baie Verte Peninsula, Newfoundland, Canada. The

733 Canadian Mineralogist, 49, 1523-1547.

734 Flinn, D. (1985) The Caledonides of Shetland. Pp. 1159-1172 in: The Caledonide Orogeny

735 - Scandinavia and related Areas (D. G. Gee and B. A. Sturt, editors.). John Wiley and

$736 \quad$ Sons Ltd.

737 Fuchs, W.A. and Rose, A.W. (1974) The Geochemical Behavior of Platinum and Palladium

738 in the Weathering Cycle in the Stillwater Complex, Montana. Economic Geology, 69,

$739 \quad 332-346$.

740 Garrels, R.M. and Christ, C.L. (1965) Solutions, minerals, and equilibria. Harper \& Row,

$741 \quad$ Publishers, New York, $450 \mathrm{p}$.

742 González-Jiménez, J.M., Griffin, W.L., Proenza, J.A., Gervilla, F., O'Reilly, S.Y., Akbulut,

743 M., Pearson, N.J. and Arai, S. (2014). Chromitites in ophiolites: How, where, when,

744 why? Part II. The crystallization of chromitites. Lithos, 189, 140-158.

745 Grammatikopoulos, T.A., Kapsiotis, A., Zaccarini, F., Tsikouras, B., Hatzipanagiotou, K. and

746 Garuti, G. (2007). Investigation of platinum-group minerals (PGM) from Pindos 
chromitites (Greece) using hydroseparation concentrates. Minerals Engineering, 20, $1170-1178$.

Hough, R., Noble, R. and Reich, M. (2011) Natural gold nanoparticles. Ore Geology Review, 42, 55-61.

Kim, W.-S. and Chao G. Y. (1991) Phase relations in the system Pd-Sb-Te. The Canadian

Kozlu, H., Prichard, H. M., Melcher, F., Fisher, P. C., Brough, C. and Stueben D. (2014) Platinum group element (PGE) mineralisation and chromite geochemistry in the Berit

Leake, R. C., Bland, D. J., Styles, M. T. and Cameron, D. G. (1991) Internal structure of Au-Pd-Pt grains from south Devon, England in relation to low temperature transport and deposition. Transactions of the Institute of Mining and Metallurgy, B Applied Earth Science, 100, B159-178.

Lord, R. A., Prichard, H. M. and Neary, C. R. (1994) Magmatic PGE concentrations and hydrothermal upgrading in the Shetland ophiolite complex. Transactions Institute Mining Metallurgy, B Applied Earth Science, 103, B87-162.

Moreno, T., Prichard, H., Lunar, R., Monterrubio, S. and Fisher, P. (1999). Formation of a secondary platinum-group minerals assemblage in chromitites from the Herbeira ultramafic massif in Cabo Ortegal, NW Spain. European Journal of Mineralogy, 11, 363-378.

Moreno, T., Gibbons, W., Prichard, H.M. and Lunar, R. (2001). Platiniferous chromitite and the tectonic setting of ultramafic rocks in Cabo Ortegal, NW Spain. Journal of the Geological Society, 158, 601-614.

Mota-e-Silva, J., Prichard, H.M., Suárez, S., Ferreira Filho, C.F. and Fisher, P.C. (2016) Supergene alteration of platinum-group minerals and the formation of Pd- 

Canadian Mineralogist, 54, 755-778.

774 Oberthür, T., Weiser, T.W. and Gast, L. (2003) Geochemistry and mineralogy of platinum-

775 group elements at Hartley Platinum Mine, Zimbabwe Part 2. Supergene redistribution

776 in the oxidized Main Sulfide Zone of the Great Dyke, and alluvial platinum group

777 minerals. Mineralium Deposita, 38, 344-355.

778 Oberthür, T., Weiser, T.W., Melcher F., Gast, L. and Wöhrl, C. (2013) Detrital platinum-

779 group minerals in rivers draining The Great Dyke, Zimbabwe. The Canadian

$780 \quad$ Mineralogist, 51, 197-222.

781 Ohnenstetter, M., Johan, Z., Coherie, A., Fouillac, A., Guerrot, C., Ohnenstetter, D.,

782 Chaussidon, M., Rouer, O., Makovicky, E., Makovicky, M., Rose-Hansen, J., Karup-

783 Moller, S., Vaughan, D., Tumer, G., Pattrick, R. A. D., Gize, A.P., Lyon, I. and

784 McDonald I. (1999) New exploration methods for platinum and rhodium deposits poor

785 in base-metal sulfides. Transactions Institute Mining Metallurgy, B Applied Earth

$786 \quad$ Science, 108, 119-150.

787 Orberger, B., Fredrich, G. and Woermann, E. (1988) Platinum-group element mineralisation

788 in the ultramafic sequence of the Acoje ophiolite block, Zambales, Philippines. Pp

789 391-380 in: Geo-Platinum Symposium Volume (H. M. Prichard, P. J. Potts, J. F. W.

$790 \quad$ Bowles, S. J. Cribb, editors). Elsevier.

791 O'Driscoll, B. and González-Jiménez, J.M. (2016) Petrogenesis of the Platinum-Group

792 Minerals. Reviews in Mineralogy \& Geochemistry, 81, 489-578.

793 Ottemann, J. and Augustithis, S.S. (1967) Geochemistry and Origin of "Platinum-Nuggets" in

794 Lateritic Covers from Ultrabasic Rocks and Birbirites of W. Ethiopia. Mineralium

795 Deposita, 1, 269-277. 
Pedersen, R.B., Johannesen, G.M. and Boyd, R. (1993) Stratiform PGE mineralisations in the ultramafic cumulates of the Leka ophiolite complex, central Norway. Economic Geology, 88, 782-803.

Prichard, H. M. (1985) The Shetland Ophiolite. Pp 1173-1184 in: The Caledonide Orogeny Scandinavia and related Areas (D. G. Gee and B. A. Sturt, editors.). John Wiley and Sons Ltd.

Prichard, H. M. and Brough, C.P. (2009) Potential of ophiolite complexes to host PGE deposits. Pp. 277-290 in: New Developments in magmatic Ni-Cu and PGE deposits (C. Li and E. M. Ripley, editors.). Geological Publishing House, Beijing.

Prichard, H. M. and Lord, R.A. (1993) An overview of the PGE concentrations in the Shetland ophiolite complex. Pp. 273-294 in: Magmatic Processes and Plate Tectonics (H. M. Prichard, T. Alabaster, N. B. Harris, C. R. Neary, editors). Volume 76, Geological Society of London.

Prichard, H.M. and Lord, R.A. (1994) Evidence for the mobility of PGE in the secondary environment in the Shetland ophiolite complex. Transactions Institute Mining Metallurgy, B Applied Earth Science, 103, 79-86.

Prichard, H. M. and Tarkian M. (1988) Platinum and palladium minerals from two PGE-rich localities in the Shetland Ophiolite Complex. The Canadian Mineralogist, 26, 979-990.

Prichard, H. M., Neary, C. R. and Potts P.J. (1986) Platinum-group minerals in the Shetland Ophiolite. Pp. 395-414 in: Metallogeny of the Basic and Ultrabasic Rocks ( M. J. Gallagher, R. A. Ixer, C. R. Neary and H. M. Prichard, editors). Transactions Institute Mining Metallurgy.

Prichard, H. M., Potts P. J., Neary C. R., Lord R. A. and Ward G. R. (1988) Development of techniques for the determination of the platinum-group elements in ultramafic rock 
complexes of potential economic significance: mineralogical studies. Commission of the European Communities. Report EUR 11631, 163 pp. ISBN 92-825-9245-6.

Prichard, H. M., Ixer, R. A., Lord, R. A., Maynard, J. and Williams N. (1994) Assemblages of platinum-group minerals and sulfides in silicate lithologies and chromite-rich rocks within the Shetland Ophiolite. The Canadian Mineralogist, 32, 271-294.

Prichard, H.M., Sá, J.H.S. and Fisher, P.C. (2001) Platinum-group mineral assemblages and

Prichard, H. M., Economou-Eliopoulos, M. and Fisher, P. C. (2008a) Platinum-group minerals in podiform chromitite in the Pindos ophiolite complex, Greece. The Canadian Mineralogist, 46, 329-341.

Prichard, H. M., Barnes, S. J., Dale, C. W., Godel, B., Fisher, P.C. and Nowell, G. M. (2017) Paragenesis of multiple platinum-group mineral populations in Shetland ophiolite

Prichard, H. M., Neary, C. R., Fisher, P. C. and O'Hara, M. J. (2008b) PGE-rich podiform chromitites in the Al'Ays Ophiolite complex, Saudi Arabia: An example of critical mantle melting to extract and concentrate PGE. Economic Geology, 103, 1507-1529. chromitite: 3D X-ray tomography and in situ Os isotopes. Geochimica et Cosmochimica Acta. Published on-line 4 April 2017, https://doi.org/10.1016/j.gca.2017.03.035.

Reith, F., Zammit, C.M., Shar, S.S., Etschmann, B., Bottrill, R., Southam, G., Ta, C., Kilburn, M., Oberthür, T., Bail, A.S. and Brugger, J (2016) Biological role in the transformation of platinumgroup mineral grains. Nature Geoscience, 9, 294-298.

Salpéteur, I., Martel-Jantin, B. and Rakotomanana, D. (1995) Pt and Pd mobility in ferralitic soils of the West Andriamena area (Magadascar). Evidence of a supergene origin of some Pt and Pd minerals. Chronique de la Recherche Minière, 520, 27-45. 
845 Suárez, S., Prichard, H. M, Velasco, F., Fisher, P. C. and McDonald, I. (2010) Alteration of

846 platinum-group minerals and dispersion of platinum-group elements during progressive

847 weathering of the Aguablanca Ni-Cu deposit (SW Spain). Mineralium Deposita, 45,

$848 \quad 331-350$.

849 Takeno, N. (2005) Atlas of Eh-pH diagrams. Intercomparison of thermodynamic databases.

$850 \quad$ Geological Survey of Japan Open File Report No.419, 287 p.

851 Tarkian, M. and Prichard, H. M. (1987) Irarsite-Hollingworthite Solid-Solution Series and

852 Other Associated Ru-, Os-, Ir-, and Rh bearing PGM's from the Shetland Ophiolite

853 Complex. Mineralium Deposita, 22, 178-184.

854 Weiser, T. W. (2002) Platinum-group minerals (PGM) in placer deposits. Pp. 721-756 in:

855 The geology, geochemistry, mineralogy and mineral beneficiation of platinum-group

856 elements. ( L. J. Cabri, editor). Canadian Institute of Mining, Metallurgy and

$857 \quad$ Petroleum, special volume 54.

858 Williams, P.A. (1990) Oxide Zone Geochemistry. Ellis Horwood Series in Inorganic

859 Chemistry, $286 \mathrm{p}$.

860 Wood, S.A. and Vlassopoulos, D. (1990) The dispersion of Pt, Pd, and Au in surficial media

861 about two PGE-Cu-Ni prospects in Quebec. The Canadian Mineralogist, 28, 649-663.

862 Zaccarini, F., Pushkarev, E., Garuti, G., Krause, J., Dvornik, G.P., Stanley, C. and Bindi, L.

863 (2013) Platinum group minerals (PGM) nuggets from alluvial-eluvial placer deposits in

864 the concentrically zoned mafic-ultramafic Uktus complex (Central Urals, Russia).

$865 \quad$ European Journal of Mineralogy, 25, 519-531.

866

867 Figure Captions

868 Figure 1. Geological map showing the locations of the Cliff and Harold's Grave podiform

869 chromitites in the Shetland ophiolite complex. 
870 Figure 2. Geological map of inset in Fig.1 showing the Cliff chromitites and associated

871 streams in detail. Sampling sites C2-12 and CS are labelled.

872

873 Figure 3. Sampling sites at Cliff. (a) General view looking west from the disused

874 chromitite pits showing all sampling sites. (b) View of the pond at the pit and of sample

875 site C2. (c) Sample site C5. (d) View of the stream meanders and sample sites C6 to C9.

876 (e) Sample site CS where the streams amalgamate and plunge over the basal thrust of the

877 ophiolite; the site nearest to the Loch of Cliff.

878

879 Figure 4. (a) Pie diagrams showing the different PGM located in the chromite-rich rocks from

880 Cliff (illustrative data, from Prichard et al. 1986 and Prichard \&Tarkian 1988), and in the

881 streams panned in this study. (b) Bar graphs showing the number of alluvial PGM recovered

882 with increasing distance from the Cliff quarries: pond exit zone (samples C3-C5), following

883 meander zone (samples C6-C9), exit of the meander downstream (samples C10-11) and basal

884 thrust (sample CS). See Table 1 for more detail.

885

886 Figure 5. Back-scattered electron images of sperrylites recovered near the disused quarries

887 from samples $\mathrm{C} 3$ to $\mathrm{C} 5$. Note the frequent cracks and jagged appearance.

888

889 Figure 6. Back-scattered electron images of sperrylites from further downstream to the 890 disused quarries from samples C6 to C11. Note more rounded appearance than in Figure 5.

891

892 Figure 7. Back-scattered electron images of composite grains of sperrylite located in the 893 streams from Cliff.

894 
895 Figure 8. Back-scattered electron images of polished sections of sperrylite and associated

896 PGM and sulfides. (a) Elongate PtFe alloy enclosed in a broken cube of sperrylite. (b) Os-

897 bearing ruarsite surrounded by an angular grain of sperrylite at the top and a $\mathrm{Cu}$-bearing

898 stibiopalladinite at the bottom. (c) Relicts of platarsite on the edge of an abraded sperrylite.

899 (d) Inclusions of millerite (NiS) in sperrylite.

900

901 Figure 9. Back-scattered electron images of Pd-antimonides from the streams draining

902 Cliff. (a-c) Pd-antimonides recovered near the disused quarries from samples C3 to C5. (a)

903 Angular stibiopalladinite in a composite grain with a Pd-sulfide. (b) Stibiopalladinite with

904 a ragged appearance and vast furrows on the surface. (c) Relict stibiopalladinite in a

905 composite grain with a euhedral Pt-Pd-Cu alloy. (d-i) Pd-antimonides from further

906 downstream to the disused quarries from samples C6 to 11. Note the extensive striation on

907 the grain surfaces in the meander zone (d-g, samples C6 to C9) and the etched appearance

908 with concave hollows further downstream (h-i, samples C10-C11). Pd-antimonides form

909 composite grains with electrum in (d) and with tetraferroplatinum in (e).

910

911 Figure 10. Ternary diagrams (at.\%) showing the composition of PGM from chromitites vs.

912 streams at Cliff, Shetland Ophiolite Complex. (a) $\mathrm{Pd}-\mathrm{Sb}-\mathrm{Cu}$ ternary plot showing the

913 composition of Pd-antimonides and Pt-alloys. Ideal phases within the Pd-Sb system are those

914 reported by Kim and Chao (1991). (b) Ru-Os-Ir and Rh-Pt-Ir ternary plots showing the

915 composition of laurite and sulfarsenides, respectively.

916

917 Figure 11. Back-scattered electron images of sulfarsenides located in the streams from

918 Cliff. (a) Aggregate of irarsite (IrAsS) grains with altered and pitted surface. (b) Single

919 grain of irarsite with an etched appearance. (c) The only composite grain of irarsite and 
920 hollingworthite (RhAsS) found in the streams. Hollingworthite surrounds irarsite in the

921 core. (d) Single grain of hollingworthite, subhedral and largely altered on surface. (e)

922 Composite grain of hollingworthite and Pd-antimonide. (f) Composite grain of

923 hollingworthite and a subhedral $\mathrm{Cu}$-Pt-Pd-bearing particle of gold.

924

925 Figure 12. Back-scattered electron images of gold grains in the stream from Cliff (a-d) and

926 from Harold's Grave (e-f). (a) Irregular grain of electrum located close to the Cliff quarries.

927 (b) Subhedral grain of pure gold with a very pitted surface located downstream, in the

928 meander zone. (c) Rounded and polished grain of electrum downstream. (d) Porous grain of

929 electrum with a delicate texture. (e, f) Globular grains of pure gold from the alluvial sands at

930 Harold's Grave.

931

932 Figure 13. Back-scattered electron images of gold and rare PGM in the source rocks. (a, b)

933 Rounded porous primary $\mathrm{Au}$, similar to the detrital electrum found in the placers. (c) Pt-Cu-

934 Ni oxidised phase. (d) Pd-Cu-Ni oxidised phase on the edge of sperrylite and in stringers

935 extending from the sperrylite. (e) Sperrylite and $\mathrm{Pd}$ antimonide with $\mathrm{Cu}$ both broken by

936 chlorite laths. Sperrylite is partially altered to a Pt-Cu-Ni-oxide. (f) Breithauptite (NiSb)

937 containing approximately $1 \%$ Pd coated on the edge by Pd antimonide which contains a

938 small grain of geversite (Pt-Sb). These altered PGE-bearing phases (c-f) are all absent in the

939 placer assemblage.

940

\section{Table Captions}

942 Table 1. Types of PGM in the Cliff chromitites and alluvial PGM recovered from the

943 associated streams. Footnote: PGM in the source rocks from Prichard et al. (1986) and

944 Prichard \& Tarkian (1988) for comparison purposes. 
946 Table 2. Types of PGM in the Harold's Grave chromitites and alluvial PGM recovered from

947 the associated streams. Footnote: PGM in the rocks are from Tarkian \& Prichard (1987).

948

949 Table 3. Quantitative EDX analyses of alluvial PGM from Cliff. 


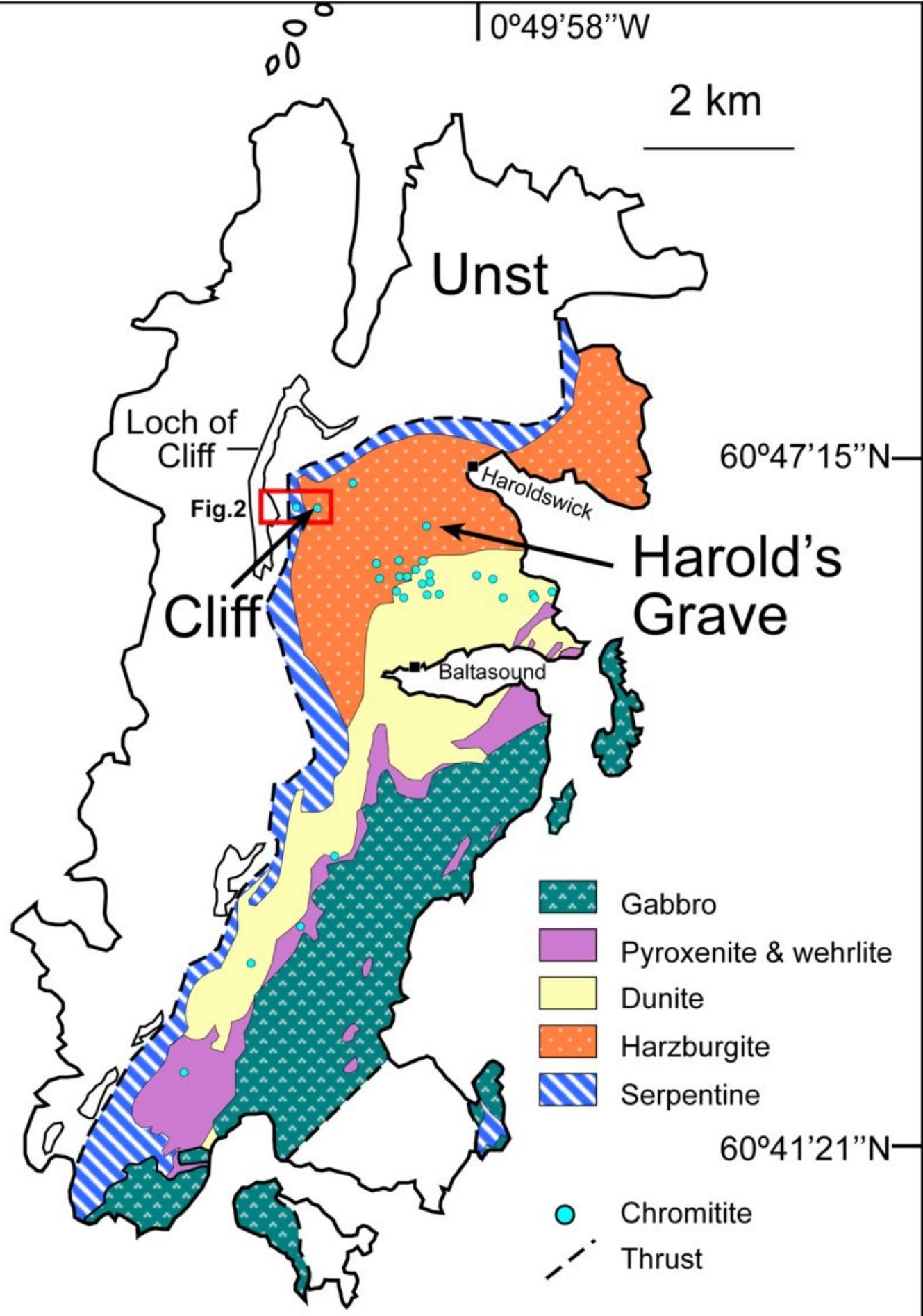




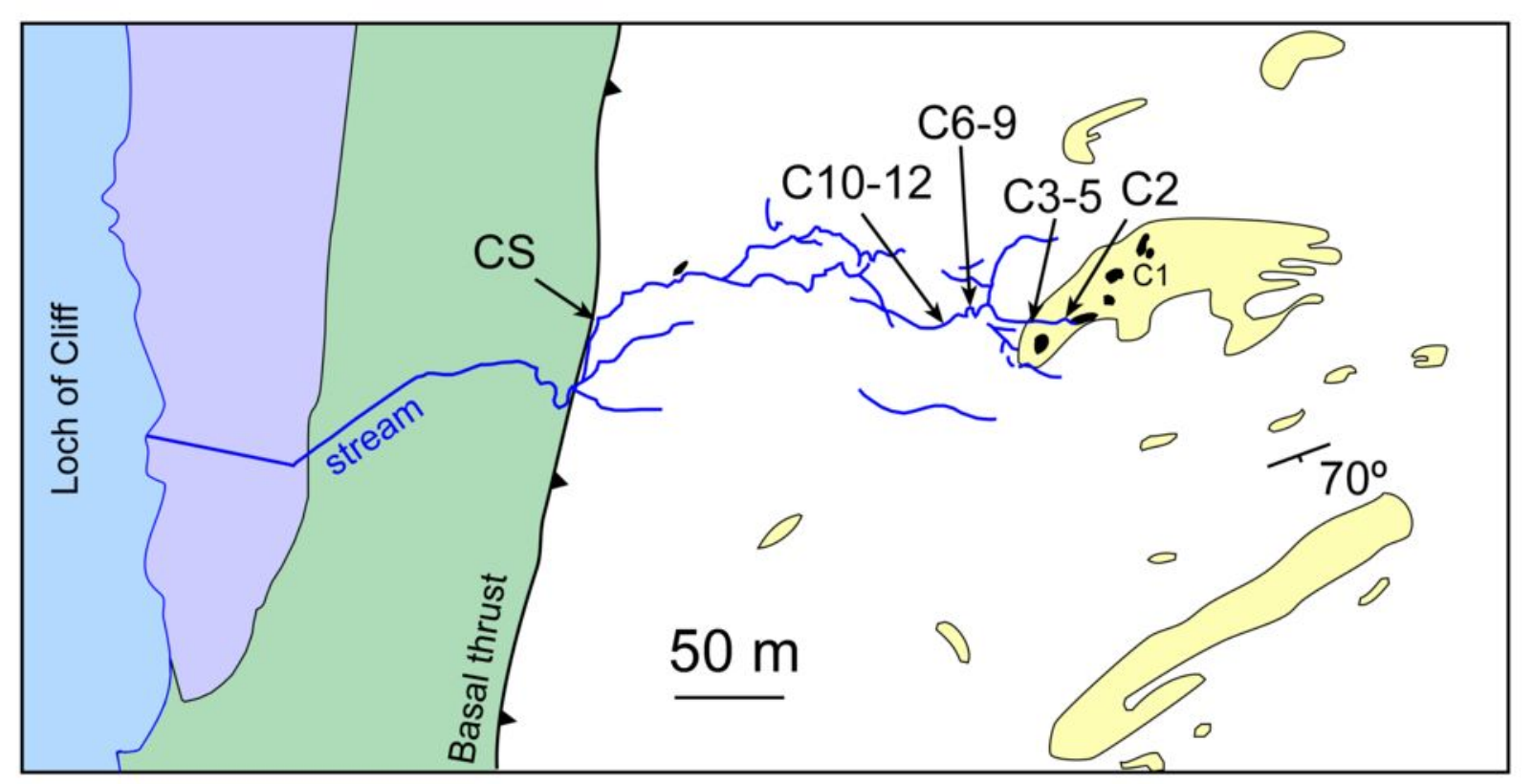

$\square$ Harzburgite $\square$ Dunite $\square$ Chromite $\square$ Greenschist $\square$ Limestone ${ }_{7} 0^{\circ}$ foliation 


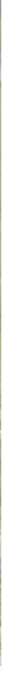

\section{b}
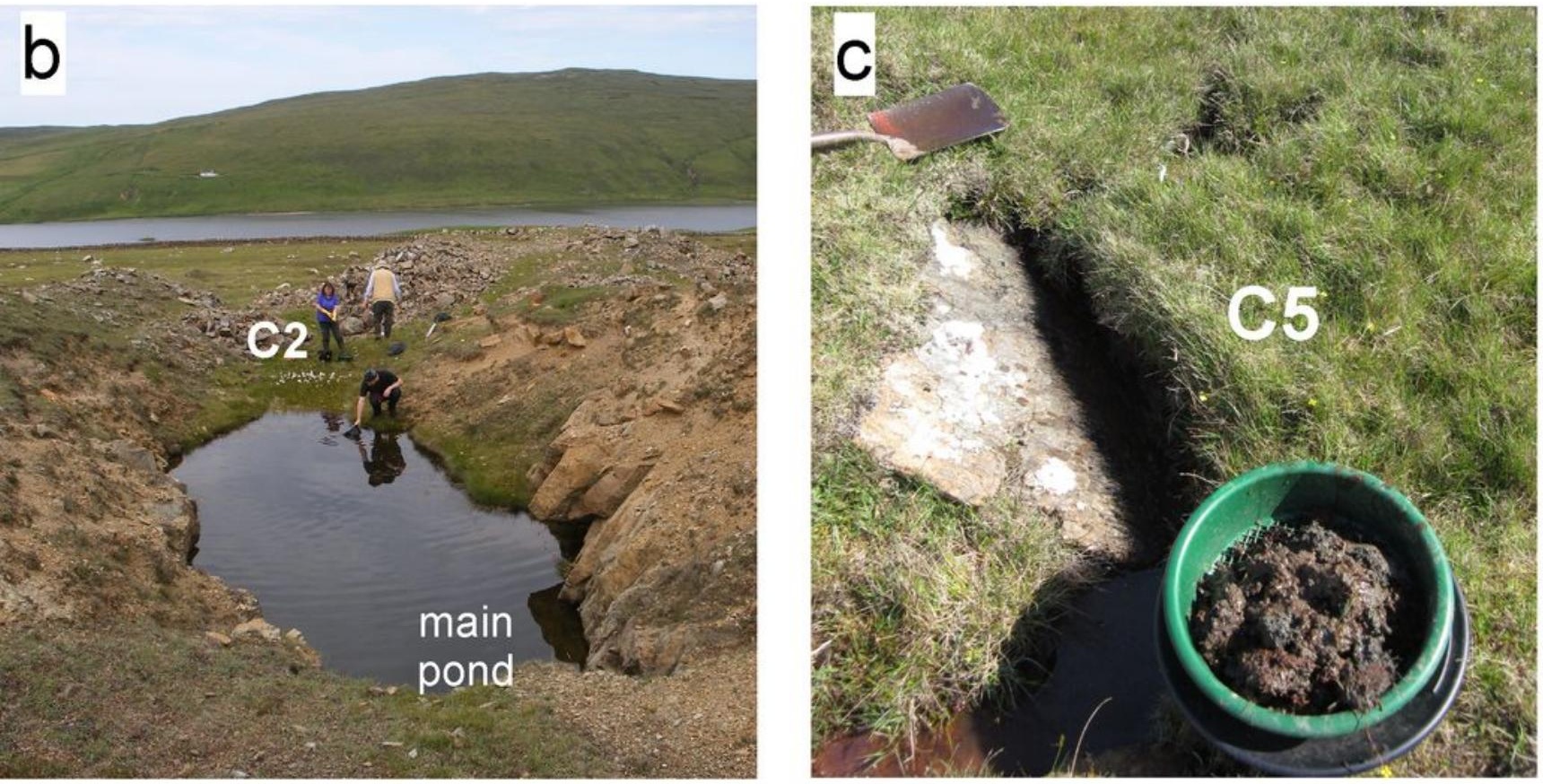

\section{d}

C9: . $2+8 \mathrm{C}_{8}$ - 75 C7. - is:?

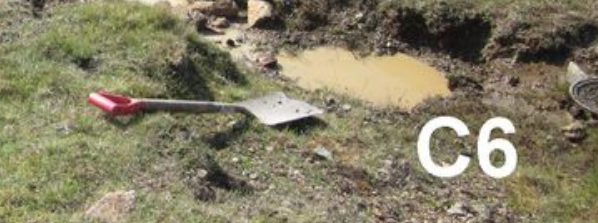

e
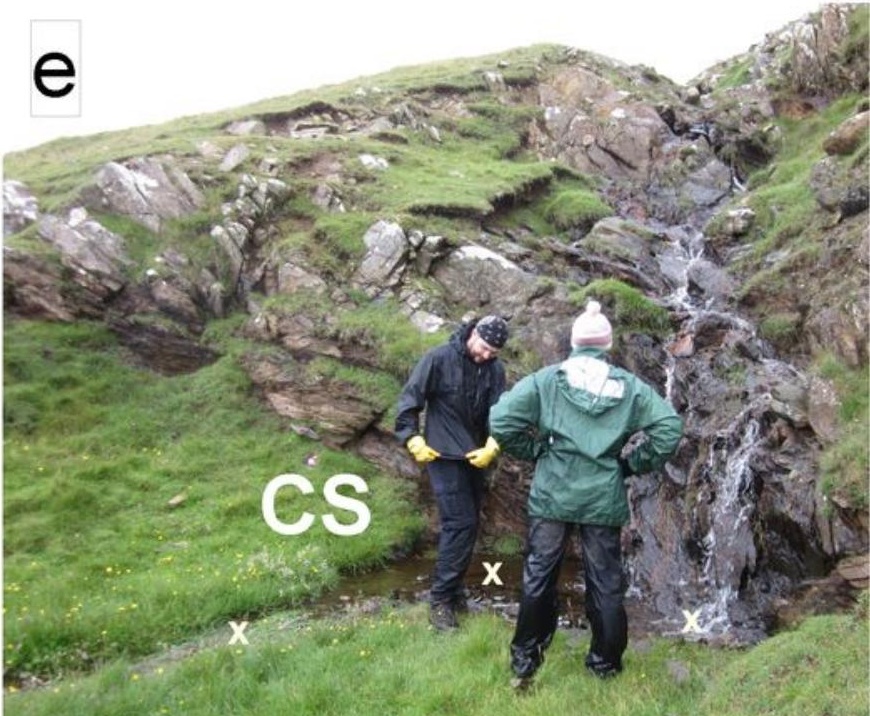


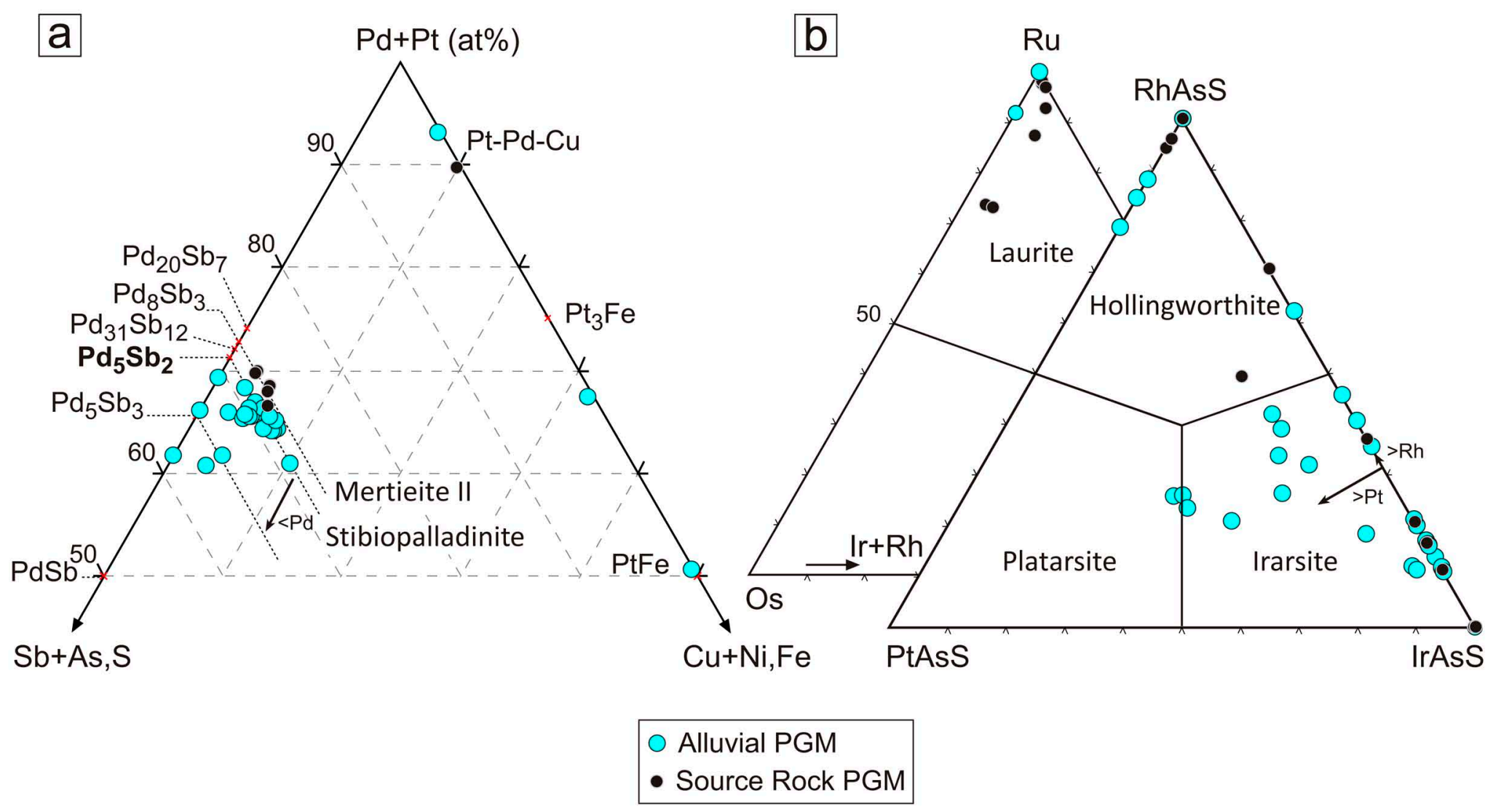


a cliff

$\overline{15 \mu \mathrm{m}}$

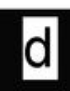

d

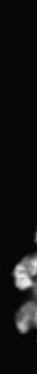

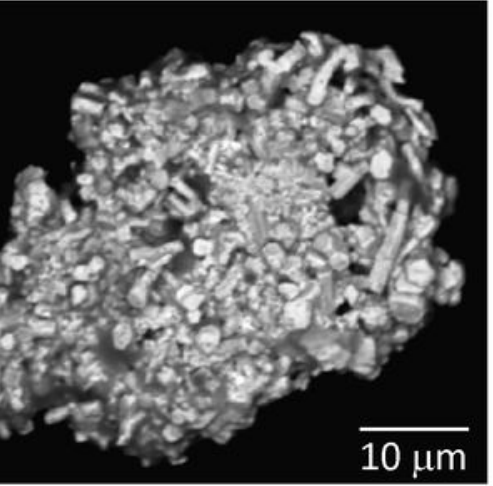

$\overline{15 \mu \mathrm{m}}$

e Harold's Grave

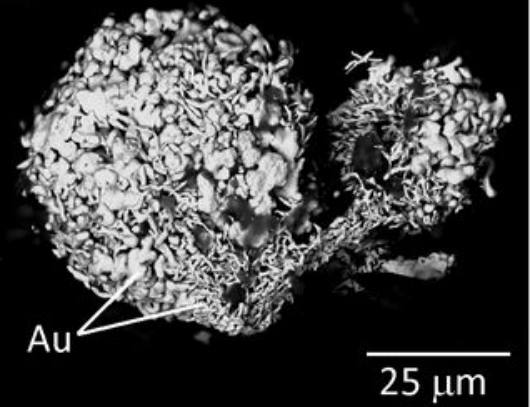

$15 \mu \mathrm{m}$

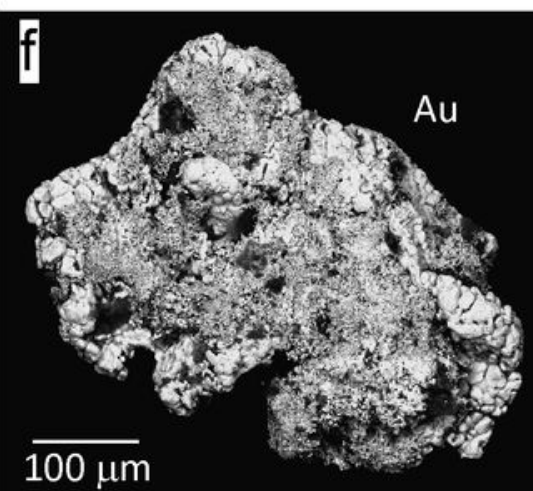


Table 1. Types of PGM in the Cliff chromitites and alluvial PGM recovered from the associated streams.

\begin{tabular}{|c|c|c|c|c|c|c|c|c|c|c|c|}
\hline \multicolumn{2}{|l|}{ 1) Source Rock* } & \multicolumn{2}{|l|}{ No. } & \multicolumn{2}{|c|}{$\sim$ Size $(\mu \mathrm{m})$} & \multicolumn{2}{|c|}{ 3) Meander (samples C6 C9) } & \multirow{2}{*}{$\begin{array}{c}\text { No. } \\
\text { grains }\end{array}$} & \multirow[b]{2}{*}{$\%$} & \multicolumn{2}{|c|}{ Size $(\mu \mathrm{m})$} \\
\hline PGM, Au & Composition & grains & $\%$ & Min & Max & PGM, Au & Composition & & & Min & Max \\
\hline Sperrylite & $(\mathrm{Pt}, \mathrm{Fe})(\mathrm{As}, \mathrm{Sb})_{2}$ & 37 & 38.1 & 4 & 20 & Sperrylite & $(\mathrm{Pt}, \mathrm{Rh})(\mathrm{As}, \mathrm{Sb})_{2}$ & 42 & 60.9 & 30 & 110 \\
\hline Hongshiite & $\mathrm{PtCu}+(\mathrm{Ni}-\mathrm{Cu})$ & 1 & 1.0 & 4 & 5 & Pt-alloys & $\mathrm{Pt}(\mathrm{Fe}, \mathrm{Ni}, \mathrm{Cu})$ & 1 & 1.4 & 15 & 20 \\
\hline Pt-alloys & $\mathrm{Pt}-\mathrm{Pd}-\mathrm{Au}-\mathrm{Cu} ; \mathrm{Pd}-\mathrm{Cu}$ & 4 & 4.1 & 2 & 8 & Pd-antimonide & $(\mathrm{Pd}, \mathrm{Fe}, \mathrm{Cu})_{5}(\mathrm{Sb}, \mathrm{As}, \mathrm{S})_{2}$ & 9 & 13.0 & 34 & 85 \\
\hline Pd-antimonide & $\mathrm{Pd}_{5} \mathrm{Sb}_{2}-\mathrm{Pd}_{11} \mathrm{Sb}_{4}$ & 24 & 24.7 & 4 & 17 & Pd-arsenide & $(\mathrm{Pd}, \mathrm{Fe}, \mathrm{Ni})_{2}(\mathrm{As}, \mathrm{S})$ & 1 & 1.4 & 15 & 20 \\
\hline $\mathrm{Ni}$-(Ru)-sulfide & $(\mathrm{Ni}, \mathrm{Fe}, \mathrm{Ru}, \mathrm{Cr})_{9} \mathrm{~S}_{8}$ & 4 & 4.1 & 10 & 30 & Pd-sulfide & $(\mathrm{Pd}, \mathrm{Pt}, \mathrm{Ni}, \mathrm{Fe}) \mathrm{S}$ & 2 & 2.9 & 13 & 70 \\
\hline Potarite & $\mathrm{PdHg}$ & 1 & 1.0 & 2 & 3 & Irarsite & $(\mathrm{Ir}, \mathrm{Rh}, \mathrm{Pt}) \mathrm{AsS}$ & 4 & 5.8 & 44 & 63 \\
\hline Irarsite & IrAsS & 9 & 9.3 & 10 & 60 & Hollingworthite & $(\mathrm{Rh}, \mathrm{Pt}) \mathrm{AsS}$ & 3 & 4.3 & 10 & 80 \\
\hline Hollingworthite & RhAsS & 7 & 7.2 & 7 & 19 & Laurite & $\mathrm{RuS}_{2}$ & 1 & 1.4 & 20 & 45 \\
\hline Rh-antimonide & Rh-Sb-S & 1 & 1.0 & 3 & 4 & Gold & $\mathrm{Au}-(\mathrm{Ag}) ; \mathrm{Au}-(\mathrm{Cu}, \mathrm{Pt}, \mathrm{Pd})$ & 6 & 8.7 & 31 & 48 \\
\hline Laurite & $\mathrm{RuS}_{2}$ & 3 & 3.1 & 10 & 27 & Total & & 69 & 100 & 24 & 60 \\
\hline Osmium & Os & 1 & 1.0 & 2 & 5 & & & & & & \\
\hline Gold & $\mathrm{Au}-(\mathrm{Pd}), \mathrm{Au}-\mathrm{Cu}$ & 5 & 5.2 & 3 & 4 & & & & & & \\
\hline Total & & 97 & 100 & 5 & 17 & & & & & & \\
\hline \multicolumn{2}{|c|}{ 2) Exit Pond (samples C3 C5) } & \multicolumn{2}{|l|}{ No. } & \multicolumn{2}{|c|}{ Size $(\mu \mathrm{m})$} & \multicolumn{2}{|c|}{ 4) Exit meander (samples C10 C11) } & \multicolumn{2}{|l|}{ No. } & \multicolumn{2}{|c|}{ Size $(\mu \mathrm{m})$} \\
\hline PGM, Au & Composition & grains & $\%$ & Min & Max & PGM, Au & Composition & grains & $\%$ & Min & Max \\
\hline Sperrylite & $(\mathrm{Pt}, \mathrm{Rh})(\mathrm{As}, \mathrm{Sb})_{2}$ & 14 & 56.0 & 14 & 92 & Sperrylite & $\mathrm{PtAs}_{2}$ & 13 & 61.9 & 22 & 106 \\
\hline Pt-alloys & Pt-Pd-Cu alloy & 1 & 4.0 & 10 & 50 & Pt-alloys & $\mathrm{Pt}_{3}(\mathrm{Fe}, \mathrm{Ni}, \mathrm{Cu})$ & 1 & 4.8 & 57 & 62 \\
\hline Pd-antimonide & $(\mathrm{Pd}, \mathrm{Cu})_{5}(\mathrm{Sb}, \mathrm{S}, \mathrm{As})_{2}$ & 5 & 20.0 & 19 & 90 & Pd-antimonide & $(\mathrm{Pd}, \mathrm{Cu})_{5}(\mathrm{Sb}, \mathrm{S}, \mathrm{As})_{2}$ & 4 & 19.0 & 36 & 103 \\
\hline Pd-sulfide & $\mathrm{Pd}_{16}(\mathrm{~S}, \mathrm{As})_{7}$ & 2 & 8.0 & 8 & 20 & Irarsite & $(I r, \mathrm{Rh}) \mathrm{AsS}$ & 1 & 4.8 & 47 & 84 \\
\hline Irarsite & $(\mathrm{Ir}, \mathrm{Rh}) \mathrm{AsS}$ & 1 & 4.0 & 27 & 60 & Hollingworthite & $(\mathrm{Rh}, \mathrm{Os}, \mathrm{Pt}) \mathrm{AsS}$ & 1 & 4.8 & 64 & 80 \\
\hline Hollingworthite & $(\mathrm{Rh}, \mathrm{Pt}) \mathrm{AsS}$ & 1 & 4.0 & 10 & 50 & Gold & $\mathrm{Au}-(\mathrm{Pd})$ & 1 & 4.8 & 5 & 20 \\
\hline Gold & $\mathrm{Au}-(\mathrm{Ag})$ & 1 & 4.0 & 58 & 60 & Total & & 21 & 100 & 39 & 76 \\
\hline \multirow[t]{4}{*}{ Total } & & 25 & 100 & 21 & 60 & & & & & & \\
\hline & & & & & & \multicolumn{2}{|c|}{ 5) Waterfall (basal thrust, sample CS) } & No. & & \multicolumn{2}{|c|}{ Size $(\mu \mathrm{m})$} \\
\hline & & & & & & PGM & Composition & grains & $\%$ & Min & Max \\
\hline & & & & & & Laurite & $(\mathrm{Ru}, \mathrm{Os})(\mathrm{S}, \mathrm{As})_{2}$ & 1 & 100 & 10 & 32 \\
\hline
\end{tabular}

* PGM in the source rocks from Prichard et al. (1986) and Prichard \& Tarkian (1988) for comparison purposes. 
Table 2. Types of PGM in the Harold's Grave chromitites and alluvial PGM recovered from the associated streams.

\begin{tabular}{llcccc} 
1) Source Rock* & & No. & \multicolumn{3}{c}{ Size $(\mu \mathrm{m})$} \\
PGM & Composition & grains & $\%$ & Min & $\mathrm{Max}$ \\
\hline Osmium & $\mathrm{Os}$ & 49 & 47.6 & 2 & 5 \\
Laurite & $\mathrm{RuS}_{2}$ & 30 & 29.1 & 10 & 250 \\
Ni-(Ru)-sulfide & $(\mathrm{Ni}, \mathrm{Fe}, \mathrm{Ru}, \mathrm{Cr})_{9} \mathrm{~S}_{8}$ & 4 & 3.9 & 10 & 30 \\
Irarsite & $\mathrm{IrAsS}$ & 5 & 4.9 & 10 & 60 \\
Ir-antimonide & $\mathrm{Ir}-\mathrm{Sb}-\mathrm{S}$ & 1 & 1.0 & 6 & 6 \\
Hollingworthite & $\mathrm{RhAsS}$ & 4 & 3.9 & 7 & 20 \\
Rh-antimonide & $\mathrm{Rh}-\mathrm{Sb}-\mathrm{S}$ & 3 & 2.9 & 2 & 4 \\
& $\mathrm{Rh}-\mathrm{Ni}-\mathrm{Sb}$ & 1 & 1.0 & 2 & 6 \\
Hongshiite & $\mathrm{PtCu}$ & 1 & 1.0 & 4 & 5 \\
Pt-alloys & $\mathrm{Pt}-\mathrm{Pd}-\mathrm{Cu}$ & 1 & 1.0 & 5 & 6 \\
Genkinite & $(\mathrm{Pt}, \mathrm{Pd})_{4} \mathrm{Sb}_{3}$ & 2 & 1.9 & 2 & 12 \\
Pd-antimonide & $\mathrm{Pd}_{5} \mathrm{Sb}_{2}-\mathrm{Pd}_{11} \mathrm{Sb}_{4}$ & 2 & 1.9 & 3 & 17 \\
\cline { 2 - 5 } Total & & 103 & 100 & 5 & 35
\end{tabular}

\begin{tabular}{llcccc} 
2) Stream & & No. & \multicolumn{3}{c}{ Size $(\mu \mathrm{m})$} \\
PGM-Sample & Composition & grains & $\%$ & Min & Max \\
\hline Laurite (HG7) & RuS $_{2}$ & 1 & 14.3 & 35 & 50 \\
Iridium (HG7) & Ir-(Fe $>$ S,As) & 1 & 14.3 & 20 & 20 \\
Osmium (HG10) & Os-(Ir-Ru) & 1 & 14.3 & 30 & 60 \\
Gold (HG1-2-7) & Au-Ag, Au-Cu & 4 & 57.1 & 149 & 224 \\
Total & & 7 & 100 & 59 & 89
\end{tabular}

* PGM in the rocks are from Tarkian \& Prichard (1987). 
Table 3. Quantitative EDX analyses of alluvial PGM from Cliff.

\begin{tabular}{|c|c|c|c|c|c|c|c|c|c|c|c|c|c|}
\hline Analysis & 1 & 2 & 3 & 4 & 5 & 6 & 7 & 8 & 9 & 10 & 11 & 12 & 13 \\
\hline Sample & $\mathrm{C3}$ & $\mathrm{C} 5$ & C6 & $\mathrm{C9}$ & $\mathrm{C} 4$ & C6 & C10 & C6 & $\mathrm{C9}$ & $\mathrm{C} 5$ & C6 & C10 & C6 \\
\hline \multicolumn{14}{|l|}{ Wt.\% } \\
\hline $\mathrm{Pt}$ & 56.25 & 55.04 & 54.50 & 52.97 & & & & & 13.79 & 21.99 & & 77.29 & \\
\hline $\mathrm{Pd}$ & & & & & 63.20 & 64.13 & 63.78 & & & & & & \\
\hline $\mathrm{Rh}$ & 0.47 & & 1.24 & 1.11 & & & & 6.15 & 9.56 & 7.84 & & & \\
\hline Ir & & & & & & & & 55.78 & 36.64 & 20.78 & & & \\
\hline $\mathrm{Ru}$ & & 0.99 & 0.68 & 1.41 & & & & & & 8.93 & 22.00 & & \\
\hline Os & & & & & & & & & & & 37.44 & & \\
\hline $\mathrm{Au}$ & & & & & & & & & & & & & 75.69 \\
\hline $\mathrm{Ag}$ & & & & & & & & & & & & & 25.40 \\
\hline $\mathrm{Cu}$ & & & & & 4.00 & 2.73 & 3.61 & & & & & 5.42 & \\
\hline $\mathrm{Ni}$ & & & & & & 0.60 & 0.59 & & & & & 4.72 & \\
\hline $\mathrm{Fe}$ & & & & & & & & & & & & 12.11 & \\
\hline$S$ & & 0.32 & 0.49 & 1.23 & & & & 12.95 & 11.56 & 11.95 & 13.35 & & \\
\hline As & 42.12 & 41.20 & 42.25 & 40.26 & & & & 25.78 & 29.91 & 29.01 & 30.95 & & \\
\hline $\mathrm{Sb}$ & 1.23 & 2.29 & 0.92 & 2.86 & 31.80 & 31.89 & 32.49 & & & & & & \\
\hline Total & 100.07 & 99.84 & 100.08 & 99.84 & 99.00 & 99.35 & 100.47 & 100.66 & 101.47 & 100.50 & 103.73 & 99.54 & 101.1 \\
\hline \multicolumn{14}{|l|}{ At.\% } \\
\hline Pt & 33.32 & 32.41 & 31.57 & 30.32 & & & & & 6.35 & 9.84 & & 50.88 & \\
\hline $\mathrm{Pd}$ & & & & & 64.70 & 65.67 & 64.24 & & & & & & \\
\hline $\mathrm{Rh}$ & 0.53 & & 1.37 & 1.21 & & & & 5.44 & 8.34 & 6.66 & & & \\
\hline Ir & & & & & & & & 26.43 & 17.11 & 9.44 & & & \\
\hline $\mathrm{Ru}$ & & 1.12 & 0.76 & 1.56 & & & & & & 7.71 & 17.50 & & \\
\hline Os & & & & & & & & & & & 15.83 & & \\
\hline $\mathrm{Au}$ & & & & & & & & & & & & & 62.01 \\
\hline $\mathrm{Ag}$ & & & & & & & & & & & & & 37.99 \\
\hline $\mathrm{Cu}$ & & & & & 6.85 & 4.68 & 6.08 & & & & & 10.95 & \\
\hline $\mathrm{Ni}$ & & & & & & 1.12 & 1.08 & & & & & 10.32 & \\
\hline $\mathrm{Fe}$ & & & & & & & & & & & & 27.85 & \\
\hline$S$ & & 1.14 & 1.71 & 4.28 & & & & 36.79 & 32.37 & 32.54 & 33.46 & & \\
\hline As & 64.99 & 63.17 & 63.73 & 60.01 & & & & 31.34 & 35.83 & 33.81 & 33.21 & & \\
\hline \multirow[t]{2}{*}{$\mathrm{Sb}$} & 1.16 & 2.16 & 0.86 & 2.62 & 28.45 & 28.54 & 28.60 & & & & & & \\
\hline & & \multicolumn{5}{|c|}{ Analysis } & & & & & & & \\
\hline \multirow{4}{*}{\multicolumn{2}{|c|}{ Sperrylite }} & 1 & \multicolumn{11}{|c|}{$(\mathrm{Pt}, \mathrm{Rh})_{1.02}(\mathrm{As}, \mathrm{Sb})_{1.98}$} \\
\hline & & 2 & \multicolumn{11}{|c|}{$(\mathrm{Pt}, \mathrm{Ru})_{1.01}(\mathrm{As}, \mathrm{S}, \mathrm{Sb})_{1.99}$} \\
\hline & & 3 & \multicolumn{11}{|c|}{$(\mathrm{Pt}, \mathrm{Rh}, \mathrm{Ru})_{1.01}(\mathrm{As}, \mathrm{Sb}, \mathrm{S})_{1.99}$} \\
\hline & & 4 & \multicolumn{11}{|c|}{$(\mathrm{Pt}, \mathrm{Rh}, \mathrm{Ru})_{0.99}(\mathrm{As}, \mathrm{S}, \mathrm{Sb})_{2.01}$} \\
\hline \multirow{3}{*}{\multicolumn{2}{|c|}{ Pd-antimonide }} & 5 & \multicolumn{11}{|c|}{$(\mathrm{Pd}, \mathrm{Cu})_{5.01} \mathrm{Sb}_{1.99}$} \\
\hline & & 6 & \multicolumn{11}{|c|}{$(\mathrm{Pd}, \mathrm{Cu}, \mathrm{Ni}, \mathrm{Fe})_{5} \mathrm{Sb}_{2}$} \\
\hline & & 7 & \multicolumn{11}{|c|}{$(\mathrm{Pd}, \mathrm{Cu}, \mathrm{Ni})_{5} \mathrm{Sb}_{2}$} \\
\hline \multirow{2}{*}{\multicolumn{2}{|c|}{ Irarsite }} & 8 & \multicolumn{11}{|c|}{$(\mathrm{Ir}, \mathrm{Rh})_{0.96} \mathrm{As}_{0.94} \mathrm{~S}_{1.10}$} \\
\hline & & 9 & \multicolumn{11}{|c|}{$(\mathrm{Ir}, \mathrm{Rh}, \mathrm{Pt})_{0.95} \mathrm{As}_{1.08} \mathrm{~S}_{0.97}$} \\
\hline Platarsite & & 10 & \multicolumn{11}{|c|}{$(\mathrm{Pt}, \mathrm{Ir}, \mathrm{Ru}, \mathrm{Rh})_{1.01} \mathrm{As}_{1.01} \mathrm{~S}_{0.98}$} \\
\hline Ruarsite & & 11 & \multicolumn{11}{|c|}{$\left(\mathrm{Ru}_{0.52} \mathrm{Os}_{0.47}\right) \mathrm{AsS}$} \\
\hline Pt-alloy & & 12 & \multicolumn{11}{|c|}{$\mathrm{Pt}_{1.02}\left(\mathrm{Fe}_{0.56} \mathrm{Cu}_{0.22} \mathrm{Ni}_{0.20}\right)_{0.98}$} \\
\hline Electrum & & 13 & $\mathrm{Au}_{0.62} \mathrm{Ag}$ & 0.38 & & & & & & & & & \\
\hline
\end{tabular}

